\title{
Gelişmekte Olan Ülkelerin Finansal Derinleşme Açısından Sınıflandırılmasına iliş̧kin Bir Uygulama ${ }^{1}$
}

\begin{abstract}
Gelişmekte Olan Ülkelerin Finansal Derinleşme Açısından Sınıflandırılmasına İlişkin Bir Uygulama

Öz

Finansal derinleşme finansal sistemde biriktirilen fonların reel sektöre ne ölçüde aktarıldığını göstermekte ve finansal derinleşme düzeyi arttıkça ülkeler finansal ve ekonomik açıdan daha fazla gelişebilmektedir. Finansal derinleşme düzeyi gelişmiş ve gelişmekte olan ülkeler açısından farklılık göstermekte ve finansal derinleşme düzeyinin yükseltilmesinde her bir ülkede dikkate alınacak faktörler de ülkelerin finansal, ekonomik, politik, sosyal ve kurumsal yapılarına göre değişebilmektedir. Çalışmanın amacı gelişmekte olan hangi ülkelerin finansal derinleşme açısından farklı, hangilerinin benzer özellikler gösterdiğini belirlemektir. Bu amacı gerçekleştirmek için çalışmada gelişmekte olan 17 ülkenin 1997 - 2014 dönemini kapsayan finansal derinleşme verileriyle kümeleme analizi yapılmıştır. Analiz sonucunda ülkeler finansal derinleşme açısından dört farklı sınıfa ayrılmış ve finansal derinleşme açısından benzer olan ülkeler aynı kümede, benzer olmayan ülkeler farklı kümelerde yer almışlardır.
\end{abstract}

Anahtar Kelimeler: Finansal Derinleşme, Temel Bileşenler Analizi, Kümeleme Analizi
Arzu Özmerdivanlı ${ }^{2}$

Veli $\mathrm{Akel}^{3}$

An Application for Classification of Developing Countries in Terms of Financial Deepening

\section{Abstract}

Financial deepening shows to extend to which the funds saved in the financial system are transferred real sector and as the level of financial deepening increases countries can develop more economically and financially. The level of financial deepening differs in terms of developed and developing countries. Factors to be taken into consideration in each country can be changed according to the financial, social and institutional structures of the countries in the increase of the level of financial deepening. The aim of the study is to determine which developing countries are different from each other in terms of financial deepening and which have similar characteristics. In order to achieve this aim, a cluster analysis was carried out on 17 emerging countries with financial deepening data covering the period from 1997 to 2014. As a result of the analysis, the countries were divided into four groups in terms of financial deepening and the countries with similar financial deepening were in the same cluster and the non-similar countries were in different clusters.

Keywords: Financial Deepening, Principal Component Analysis, Cluster Analysis

\section{Giriş}

Küçük tasarrufların bir araya getirilip reel sektöre aktarılmasıyla, ekonomiye can veren yatırımların gerçekleştirilmesine katkı sağlayan finansal sistem, gelişmiş ülkelerde olduğu gibi gelişmekte olan ülkelerin de hem ekonomik, hem de finansal gelişimini etkileyen en önemli sistemlerden biridir. Finansal sistemin, fon arz edenler ile fon talep edenler arasında bir köprü işlevi yaparak fonların transferini gerçekleştirmesi, ekonomik gelişme açısından oldukça önemli olan bir fonksiyondur. Fon transferi sayesinde tasarruflar yatırımlara kanalize edilebilmekte, fonlar reel sektöre aktarılabilmekte ve yatırımların, buna bağlı olarak da istihdamın artmasıyla ekonomik büyüme hız kazanabilmektedir.

\footnotetext{
${ }^{1}$ Bu çalışma Erciyes Üniversitesi Sosyal Bilimler Enstitüsü İşletme Anabilim Dalı’nda Doç. Dr. Veli Akel danışmanlığında Arzu Özmerdivanlı tarafından " Finansal Derinleşmeyi Etkileyen Faktörler: Gelişmekte Olan Ülkeler Üzerine Bir Uygulama" ismiyle tamamlanarak 30.05.2017 tarihinde savunulan doktora tezinden türetilmiştir.

2 Dr. Öğr. Üyesi, Karamanoğlu Mehmetbey Üniversitesi UBYO, Bankacılık ve Sigortacılık Bölümü. arzuoz@kmu.edu.tr, yazar ORCID bilgisi: https://orcid.org/0000-0002-2120-3312.

3 Prof. Dr., Erciyes Üniversitesi iiBF, İşletme Bölümü. veliakel@erciyes.edu.tr, yazar ORCID bilgisi: https://orcid.org/0000-0002-5723-0910.
} 
Gelişmekte olan ülkeler finansal açıdan gelişip derinleşebildikleri ölçüde reel sektörlerini de geliştirebilecekler ve ekonomik yönden de kalkınabileceklerdir. Bunun gerçekleşebilmesi için öncelikle gelişmekte olan ülkelerin finansal derinleşme açısından diğer ülkeler arasında nasıl bir konuma sahip olduğunu bilmeleri gerekmektedir. Bu sayede her bir ülke finansal derinleşme açısından diğer ülkelerle hangi benzerlik ve farklılıklara sahip olduğunu ve finansal açıdan gelişebilmek için hangi ölçütlere odaklanması gerektiğini daha iyi anlayabilecek ve daha etkin politikalar geliştirebilecektir. Bu bağlamda çalışmanın amacı, gelişmekte olan hangi ülkelerin finansal derinleşme açısından farklı, hangilerinin benzer özellikler gösterdiğini belirlemektir. Bu amacı gerçekleştirebilmek için çalışmada, gelişmekte olan 17 ülkenin 1997 - 2014 dönemine ait yıllık verileri ve kümeleme analizi kullanılarak finansal derinleşme açısından sınıflandırılmasına yönelik bir uygulamaya yer verilmektedir.

Çalışmada öncelikle finansal derinleşme ve finansal derinleşmenin ölçülmesinde kullanılan göstergeler ele alınacak, ardından analizde kullanılan yöntem ve veri seti tanıtılacak ve analiz sonuçlarının genel olarak değerlendirilmesiyle çalışma sonlandırılacaktır.

\section{Finansal Derinleşme}

Genel anlamda finansal derinleşme, finansal sistemde yaratılan ve biriken fonların reel sektöre aktarılma oranı olarak tanımlanmaktadır (Erim ve Türk, 2005: 23). Bir başka tanıma göre finansal derinleşme, reel ekonomi ile ilişkili olarak gerçekleştirilen finansal işlemlerin oranındaki artışı göstermektedir. Finansal derinleşme süreci, reel ekonomiye ilişkin finansal varlık bilançosundaki genişleme olarak da yorumlanabilir (Hamori ve Hashiguchi, 2012: 353).

Bir ülkede finansal sistemde biriken fonların reel sektöre aktarılarak etkin ve verimli bir şekilde kullanılabilmesi için finansal derinleşme düzeyinin ölçülmesi gerekmektedir. Finansal derinleşmenin ölçülebilmesi için kapsamlı göstergelere ihtiyaç duyulmaktadır. Finansal derinleşmenin ölçümünde kullanılacak göstergelerin, finansal sistemin likidite yönetimine, kredi aracllığına ve risk yönetimine ilişkin özelliklerini kapsaması gerekmektedir. Ayrıca, finansal sistemin gelişmişliğini ve derinliğini belirleyebilmek için fiyat ayarlamalarını ve fiyat esnekliklerini içine alacak şekilde finansal fiyatlama mekanizmalarının da detaylı bir şekilde göz önünde bulundurulması gerekmektedir. Teorik literatür incelendiğinde finansal derinleşmenin ölçümünde kullanılan göstergelerin miktar göstergeleri, yapısal göstergeler, finansal fiyatlar, ürün çeşitliliği ve işlem (değişim) maliyeti olmak üzere beş sınıfta incelendiği görülmektedir (Lynch, 1996: 6).

Tablo 1: Finansal Derinleşmenin Ölçülmesinde Kullanılan Göstergeler

\begin{tabular}{|c|c|c|c|}
\hline \multicolumn{3}{|l|}{ Göstergeler } & \multirow{2}{*}{$\begin{array}{l}\text { Açıklaması } \\
\text { Hane halkının bankacılık sektörünü kullanım düzeyi ile il- } \\
\text { gili bilgiler sunar (Ağır, 2010: 90-91). }\end{array}$} \\
\hline & & M2/GSYH & \\
\hline & Parasal & M2Y/GSYH & $\begin{array}{l}\text { M2Y döviz tevdiat hesaplarını içermekte ve bankacılık } \\
\text { sektöründe döviz tevdiat hesaplarının da kullanıldığı göz } \\
\text { önünde bulundurularak çalışmalarda kullanılmaktadır } \\
\text { (Ağır, 2010: 90-91). }\end{array}$ \\
\hline & & M3/GSYH & $\begin{array}{l}\text { M3’ün bankalar aracıllı̆ıyla ödünç verilecek fonları temsil } \\
\text { ettiği varsayılmakta (Erim ve Türk, 2005: 27) ve bu oran } \\
\text { finansal derinleşmenin bir göstergesi olarak çalışmalarda } \\
\text { kullanılmaktadır. }\end{array}$ \\
\hline
\end{tabular}




\begin{tabular}{|c|c|c|c|}
\hline \multirow{7}{*}{$\begin{array}{l}\text { Miktar } \\
\text { Göstergeleri }\end{array}$} & $\begin{array}{l}\text { Kredilere } \\
\text { İlişkin }\end{array}$ & $\begin{array}{l}\text { Yurt İçi Toplam Kredi- } \\
\text { ler/GSYH } \\
\text { Özel Sektöre Verilen Yurt } \\
\text { İçi Krediler/GSYH } \\
\text { Özel Sektöre Verilen Yurt } \\
\text { İçi Krediler/ Toplam Yurt } \\
\text { İçi Krediler }\end{array}$ & $\begin{array}{l}\text { Bankalar topladıkları mevduatlarla, kredileri finanse et- } \\
\text { tikleri için bu göstergeler ekonomi içerisinde finansal } \\
\text { aracılık düzeyinin bir ölçüsü olarak hizmet etmektedirler } \\
\text { (Lynch, 1996: 7).Banka kaynaklarının ne düzeyde yatırım- } \\
\text { lara kanalize edildiğini göstermekte olup bu oranların } \\
\text { yüksek olması finansal derinleşmeyi olumlu etkilemekte- } \\
\text { dir. }\end{array}$ \\
\hline & \multirow{5}{*}{$\begin{array}{l}\text { Sermaye } \\
\text { Piyasala- } \\
\text { rına İlişkin }\end{array}$} & $\begin{array}{l}\text { Hisse Senedi Piyasasında } \\
\text { İşlem Gören Hisse Senet- } \\
\text { lerinin Toplam Piyasa De- } \\
\text { ğeri/GSYH (Piyasa Kapita- } \\
\text { lizasyon Oranı) }\end{array}$ & \multirow{3}{*}{$\begin{array}{l}\text { Hisse senedi piyasasında gerçekleşen faaliyetlerin düze- } \\
\text { yini ve bir ekonomide hisse senedi piyasasının ne dü- } \\
\text { zeyde önemli olduğunu göstermektedir (Demirgüç- } \\
\text { Kunt ve Maksimoviç, 1996: 294-295). }\end{array}$} \\
\hline & & $\begin{array}{l}\text { Piyasadaki Şirketlerin Sa- } \\
\text { yısı } \\
\text { Hisse Senedi İşlem } \\
\text { Hacmi/GSYH }\end{array}$ & \\
\hline & & $\begin{array}{l}\text { Hisse Senedi İşlem Hacmi/ } \\
\text { Piyasa Kapitalizasyonu } \\
\text { (hisse senedi piyasası de- } \\
\text { vir hızı) }\end{array}$ & \\
\hline & & Yoğunlaşma Değişkeni & $\begin{array}{l}\text { Piyasadaki en büyük } 10 \text { hisse senedinin, toplam piyasa } \\
\text { değeri içerisindeki payı ile ölçülmektedir(Demirgüç - } \\
\text { Kunt ve Levine, 1996: 298-301). }\end{array}$ \\
\hline & & Volatilite Değişkeni & $\begin{array}{l}\text { Hisse senetlerinin bir yıl içerisindeki standart hatalarıyla } \\
\text { ölçülmektedir(Demirgüç - Kunt ve Levine, 1996: 298- } \\
\text { 301). }\end{array}$ \\
\hline & $\begin{array}{l}\text { Mali Var- } \\
\text { lık Sto- } \\
\text { kuna Illiş- } \\
\text { kin }\end{array}$ & $\begin{array}{l}\text { Toplam Mali Varlık } \\
\text { Stoku/GSYH }\end{array}$ & $\begin{array}{l}\text { Mali varlık stoku, parasal göstergeler, döviz tevdiat he- } \\
\text { saplarını da kapsayan bankacılık sistemi toplam mevdu- } \\
\text { atı, kamu ve özel sektörün ihraç ettiği finansal araçlar ve } \\
\text { finansal aracı kurumların toplam varlıkları toplamından } \\
\text { oluşmaktadır. Bu göstergenin finansal derinleşme ile bir- } \\
\text { likte yükseleceği beklenmekte ve yüksek olduğu du- } \\
\text { rumda da finansal derinleşmeyi olumlu etkileyeceği bek- } \\
\text { lenmektedir (Ağır, 2010: 93). }\end{array}$ \\
\hline \multirow{3}{*}{$\begin{array}{l}\text { Yapısal } \\
\text { Göstergeler }\end{array}$} & $\mathrm{M} 2 / \mathrm{M} 1$ & & $\begin{array}{l}\text { Bir ülkenin finansal gelişmişlik derecesiyle pozitif olarak } \\
\text { ilişkilidir (Lynch, 1996: 10-11). }\end{array}$ \\
\hline & \multicolumn{2}{|c|}{$\begin{array}{l}\text { Menkul Kıymet Piyasasında Dolaşımda } \\
\text { Olan Menkul Değerlerin Geniş Para Ar- } \\
\text { zına Oranı }\end{array}$} & $\begin{array}{l}\text { Finansal sistemde menkul kıymet piyasaları ile aracılar } \\
\text { arasındaki dengeyi göstermektedir (Lynch, 1996: 10-11). }\end{array}$ \\
\hline & \multicolumn{2}{|c|}{$\begin{array}{l}\text { Türev Araçların Devir Hızının Dayanak } \\
\text { Varlığa İlişkin Piyasalardaki Devir Hızına } \\
\text { Oranı }\end{array}$} & $\begin{array}{l}\text { Bilanço dışı risk yönetim araçlarının önemini ölçmektedir } \\
\text { (Lynch, 1996: 10-11). }\end{array}$ \\
\hline $\begin{array}{l}\text { Finansal } \\
\text { Fiyatlar }\end{array}$ & \multicolumn{2}{|c|}{ Reel Faiz Oranları (Kredi ve Mevduat) } & $\begin{array}{l}\text { Belirli malları içine alan bir sepetin mal birimleri ile ifade } \\
\text { edilmekte olup pozitif reel faiz oranları finansal derinleş- } \\
\text { menin ön koşuludur (Erim ve Türk, 2005: 26; Lynch, } \\
\text { 1996: 12). }\end{array}$ \\
\hline $\begin{array}{l}\text { İşlem } \\
\text { Maliyeti }\end{array}$ & \multicolumn{3}{|c|}{$\begin{array}{l}\text { Genel olarak faiz oranı ile ölçülmekte olup kredi ve mevduat faizi arasındaki fark olarak ifade edil- } \\
\text { mektedir (Ağır, 2010: 96). }\end{array}$} \\
\hline $\begin{array}{l}\text { Ürün } \\
\text { Çeşitliliği }\end{array}$ & \multicolumn{3}{|c|}{$\begin{array}{l}\text { Finansal araçların çeşitliliğinin ölçülmesinde kullanılan bir oran olmamakla birlikte, finansal piyasa- } \\
\text { larda kullanılan araçların sayısı incelenerek bir finansal sistemdeki finansal araçların çeşitliliği hak- } \\
\text { kında bilgi edinilebilir. }\end{array}$} \\
\hline
\end{tabular}

Kaynak: Literatür dikkate alınarak yazar tarafından oluşturulmuştur. 


\section{Eskişehir Osmangazi Üniversitesi Iïß Dergisi}

Finansal derinleşme, çok yönlü ve içerisinde birçok unsuru barındıran, ülkelerin finansal ve ekonomik gelişmesinde oldukça önemli olan bir kavramdır. Bu nedenle ulusal ve uluslararası uygulamalı literatürde finansal derinleşme uzun yıllardan beri incelenmiş ve hala incelenmeye devam etmektedir. Ulusal ve uluslararası uygulamalı literatürde finansal derinleşme göstergelerini kullanan çalışmalar Tablo 2'de sunulmuştur.

Tablo 2: Ulusal ve Uluslararası Uygulamalı Literatürde Finansal Derinleşme Göstergelerinin Kullanıldığı Çalışmalar

\begin{tabular}{|c|c|}
\hline Gösterge & Yazarlar \\
\hline M2/GSYH & $\begin{array}{l}\text { Jung, 1986; Graff ve Karmann, 2006; Akinboade ve Kinfack, 2013; } \\
\text { Nzotta ve Okereke, 2009; Hamori ve Hashiguchi, 2012; Ağır, 2010; Öz- } \\
\text { türk vd., } 2010\end{array}$ \\
\hline $\mathrm{M} 2 \mathrm{Y} / \mathrm{GSYH}$ & Abu Bader ve Abu Quarn, 2008; Erdem ve Yamak, 2014 \\
\hline M3/Nominal GSYH & Ang ve McKibbin, 2007; Huang, 2006; Öztürk vd., 2010; Gries vd. 2009 \\
\hline $\begin{array}{c}\text { Özel Sektöre Verilen Yurt İçi Krediler/Nominal } \\
\text { GSYH }\end{array}$ & $\begin{array}{l}\text { Abu Bader ve Abu Quarn, 2008; Ang ve McKibbin, 2007; Huang, 2006; } \\
\text { Ağır, 2010; Öztürk vd., 2010; Akinboade ve Kinfack, 2013; Gries vd., } \\
\text { 2009; Nzotta ve Okereke, 2009; Hamori ve Hashiguchi, } 2012\end{array}$ \\
\hline Özel Sektöre Verilen Krediler/Yurt İçi Krediler & Akinboade ve Kinfack, 2013; Levine, 1997 \\
\hline Yurt İçi Kredi Hacmi/GSYH & Ağır, 2010 \\
\hline Yurt İçi Krediler/GSYH & Akinboade ve Kinfack, 2013; Liang ve Teng, 2006; Öztürk vd., 2010 \\
\hline Toplam Banka Kredileri/GSYH & Hasan vd., 2009 \\
\hline Özel Sektöre Verilen Banka Kredileri/GSYH & Herrer vd., 2002; Levine, 1997; Öztürk vd., 2010 \\
\hline $\begin{array}{l}\text { Finansal Olmayan Özel Sektör Firmalarına Veri- } \\
\text { len Krediler /Yurt İçi Krediler }\end{array}$ & Abu Bader ve Abu Quarn, 2008 \\
\hline $\begin{array}{c}\text { Banka Kredileri/Ticari Banka Kredileri + Merkez } \\
\text { Bankası Varlıkları }\end{array}$ & Levine, 1997 \\
\hline $\begin{array}{l}\text { Ticari (Mevduat) Bankanın Varlıkları/(Ticari } \\
\text { Banka Varlıkları + Merkez Bankasının Varlıkları) }\end{array}$ & Ang ve McKibbin, 2007; Huang, 2006; Gries vd., 2009 \\
\hline Bankaların Varlıkları/GSYH & Huang, 2006 \\
\hline Banka Mevduatları/GSYH & $\begin{array}{l}\text { Akinboade ve Kinfack, 2013; Gries vd., 2009; Herrero vd., 2002; Liang } \\
\text { ve Teng, } 2006\end{array}$ \\
\hline $\begin{array}{l}\text { Mevduat Bankalarının Toplam Mevduat Yü- } \\
\text { kümlülükleri/GSYH }\end{array}$ & Luintel ve Khan, 1999 \\
\hline $\begin{array}{l}\text { Devir (Dönüşüm) Hızı = İşlem Gören Toplam } \\
\text { Hisselerin Değeri / Piyasa Kapitalizasyon Değeri }\end{array}$ & Huang, 2006 \\
\hline $\begin{array}{c}\text { Hisse Senedi Piyasasının Toplam Piyasa De- } \\
\text { ğeri/GSYH }\end{array}$ & Huang, 2006 \\
\hline İMKB (Hisse Senedi Piyasası) İşlem Hacmi/GSYH & Ağır, 2010 \\
\hline Hisse Senedi Piyasa Kapitalizasyonu/GSYH & Öztürk vd., 2010; Herrero vd., 2002; Khan vd., 2001 \\
\hline Finansal Sistemin GSYH İçindeki Payı & Graff ve Karmann, 2006 \\
\hline $\begin{array}{c}\text { Finansal Sistemde İstihdam Edilen İş Gücünün } \\
\text { Oranı }\end{array}$ & Graff ve Karmann, 2006 \\
\hline Finansal Tasarruflar/GSYH & Nzotta ve Okereke, 2009 \\
\hline Toplam Finansal Varlıklar/GSYH & Herrero vd.,2002 \\
\hline $\begin{array}{c}\text { Kamu ve Özel Sektör Tahvil Piyasa Kapitalizas- } \\
\text { yonu/GSYH }\end{array}$ & Khan vd., 2001 \\
\hline
\end{tabular}

Kaynak: Literatür dikkate alınarak yazar tarafından oluşturulmuştur. 
Tablo 2. finansal derinleşme ölçütü olarak parasal büyüklüklerin çalışmalarda çok sık kullanıldığını göstermektedir. Parasal büyüklükler ekonomide tasarruf büyüklüğünü de gösterdiğinden, finansal derinleşmeyi göstermesi açısından önemli bir değişken olmakla birlikte, gelişmekte olan ülkelerde enflasyonu tetikleyebilmektedir.

Tablo 2.'de görüldüğü gibi parasal büyüklüklerin dışında finansal derinleşmenin ölçülmesinde uygulamalı literatürde çok fazla kullanılan diğer bir değişken de özel sektöre verilen kredilerin GSYH ve toplam yurt içi krediler içerisindeki payıdır. Kamu sektörü dışında özel sektöre verilen krediler, finans sektörünün özel sektörü finanse etme kabiliyetini göstermekte olup finansal derinleşmenin yükselmesinde önemli rol oynamaktadır.

Finansal derinleşmenin ölçülmesinde kullanılan bankacılık sektörüne ilişkin ölçütler de Tablo 2.'de yer alan önemli değişkenlerden bazılarıdır. Banka varlıklarının, mevduatlarının veya mevduat yükümlülüklerinin GSYH içerisindeki payı şeklinde kullanılan değişkenler, bankacılık sektörünün ülke ekonomisi içerisindeki büyüklüğünü göstermekte ve bankacılık sektörüne dayalı finansal sistemlerde daha büyük değerler almaktadır.

Tablo 2.'de yer alan diğer bir finansal derinleşme ölçütü de sermaye piyasasına ilişkin değişkenlerdir. Bu değişkenler arasında hisse senedi piyasa kapitalizasyonunun GSYH içerisindeki payı, hisse senedi piyasası devir hızı, hisse senedi piyasası işlem hacmi ve tahvil piyasası kapitalizasyonunun GSYH içerisindeki payı yer almakta olup sermaye piyasasının büyüklüğü arttıkça, bu değişkenlerin aldığı değerler de yükselmektedir.

\section{Literatür Değerlendirmesi}

Gelişmekte olan ülkelerde finansal derinleşme ile ilgili olarak pek çok çalışma yapılmakta olup bu çalışmaların bazıları finansal derinleşmenin ülke bazında sınıflandırılmasını, bazıları finansal derinleşmenin alt ölçütlerinin ekonometrik analizlerle incelenmesini bazıları ise finansal derinleşme ile çeşitli değişkenler arasındaki ilişkilerin istatistiksel ve ekonometrik yöntemlerle analiz edilmesini kapsamaktadır. Bu çalışmada gerçekleştirilen uygulamalara paralel olarak literatürde finansal derinleşmenin temel bileşenler analizi ile analiz edildiği ve/veya kümeleme analizine tabi tutulduğu çalışmalar üzerinde durulacaktır.

Gelişmekte olan ülkelerde finansal derinleşme incelenirken, finansal derinleşmenin daha iyi temsil edilebilmesi için çeşitli ölçütler kullanılmaktadır. Bu ölçütler bankacılık sektörüne, parasal duruma, sermaye piyasasına, finansal sisteme ilişkin olabilmekte ve genellikle temel bileşenler analizi kullanılarak tek bir endekse indirgenmektedir. Gelişmekte olan ülkelerde finansal derinleşme ile ilgili literatür incelendiğinde, finansal derinleşme ölçülerinin temel bileşenler analizi kullanılarak sayıca azaltılması ve belirlenen ölçülerle diğer değişkenler arasında ekonometrik analizlerle ilişkinin ölçülmesine dayalı çalışmaların (Adu vd., 2013; Amarathunga, 2012) ve finansal derinleşmenin, temel bileşenler analizi kullanılarak endekse dönüştürülmesi ve sonrasında ilgili değişkenlerle ekonometrik analize tabi tutulması şeklinde yapılan çok sayıda çalışmanın (Ang ve McKibbin, 2007; Jalil vd., 2010; Sheera ve Bishnoi, 2013; Ali, 2014; Kar vd., 2014; Gries vd., 2009; Kargbo ve Adamu, 2009; Mahajan ve Verma, 2014; Sahay vd., 2015; Hussain, 2012; Adnan ve Shahzad, 2014) olduğu görülmektedir.

Ali (2014) tarafından Pakistan'da yapılan çalışmada toplam varyansın \%82.4'ünü oluşturan birinci temel bileşen finansal derinleşme temel değişkeni olarak belirlenmiş olup bu değişken dört ölçünün doğrusal bileşiminden elde edilmektedir. Bu ölçüler M2/GSYH, Banka Varlıkları/GSYH, Banka Varlıkları/Banka Varlıkları + Merkez Bankasının Varlıkları, Özel Sektöre Verilen Krediler/GSYH olup bu ölçülerin faktör skorları sırasıyla $0.4872,0.5304,0.5084$ ve 0.4720 'dir. 
Genel olarak bankacılık sektörünü temsil eden bileşenlerden oluşan finansal derinleşme temel değişkeni içerisinde Banka Varlıkları/GSYH ölçütü diğer ölçütlere göre daha yüksek (0.5304) ve pozitif değer alarak ön plana çıkmış ve endekse olumlu katkı yapmıştır.

Malezya'da finansal derinleşmenin incelendiği Ang ve McKibbin (2007)'in çalışmasında, finansal derinleşmeyi temsilen M3/GSYH, Ticari Banka Varlıkları/ (Ticari Banka Varlıkları + Merkez Bankasının Varlıkları) ve Özel Sektöre Verilen Yurt İçi Krediler/GSYH ölçütlerinin temel bileşenler analizine tabi tutulmasıyla elde edilen, bu ölçütlerin sırasıyla 0.580, 0.564 ve 0.588 katsayılarıyla hesaplandığı finansal derinleşme endeksi kullanılmıştır. Kullanılan ölçütlerin çoğunluğu bankacılık sektörü ile ilgili ve aldığı değerler birbirine yakın olmakla birlikte Özel Sektöre Verilen Yurt içi Krediler/GSYH ölçütü endeks içerisinde diğer ölçütlerden daha fazla ağırlığa (0.588) sahip olmuş ve endekse pozitif katkı yapmıştır.

Gries ve arkadaşları (2009) tarafından yapılan çalışmada 16 Sahraaltı Afrika ülkesinde finansal derinleşmeyi temsilen Ticari Banka Varlıkları/ (Ticari Banka Varlıkları + Merkez Bankasının Varlıkları), M3/GSYH ve Mevduat Bankalarının Özel Sektöre Verdiği Krediler/GSYH ölçütleri kullanılarak temel bileşenler analizi yapılmış ve analiz sonucunda Güney Afrika için sırasıyla 0.896, -0.674 ve 0.846 katsayıları elde edilmiştir. Genellikle bankacılık sektörüne ait finansal derinleşme ölçütlerinin kullanıldığı çalışmada Ticari Banka Varlıkları/ (Ticari Banka Varlıkları + Merkez Bankasının Varlıkları) ölçütü diğer ölçütlere göre daha yüksek ve pozitif değer (0.896) almış ve endekse olumlu katkı yapmıştır.

Zerbo (2015) ve Kitenge (2013) de Güney Afrika'da temel bileşenler analizi kullanarak finansal derinleşmeyi incelemişlerdir. Temel bileşenler analizi sonucunda Zerbo (2015) M2/GSYH için 0.5337, Özel Sektöre Verilen Krediler/GSYH için 0.5941 ve Bankacılık Sektörü Tarafından Özel Sektöre Sağlanan Krediler/GSYH için 0.6018 katsayısını elde etmiş olup endeks içerisinde Özel Sektöre Sağlanan Krediler/GSYH ölçütü daha fazla ağırlığa (0.6018) sahip olmuş ve endeksi pozitif yönde etkilemiştir. Kitenge (2013)'nin çalışmasında ise M3/GSYH, Mevduat Bankalarının Varlıkları/GSYH, Mevduat Bankalarının Özel Sektörden Alacakları/GSYH, Diğer Finansal Kurumların Özel Sektörden Alacakları/GSYH ölçütleri kullanılmış ve bu ölçütler için sırasıyla 0.5237, $0.4587,0.5022$ ve 0.5129 katsayıları elde etmiştir. Parasal büyüklüklerle ilgili $M 3 / G S Y H$ ölçütü en yüksek değeri (0.5237) alarak endeks içerisinde ön plana çıkmış ve endeksi pozitif yönde etkilemiştir.

Hussain ve Chakraborty (2012) tarafından Hindistan'da yapılan çalışmada, temel bileşenler analizi kullanılarak finansal derinleşme endeksi oluşturulmuştur. Bu endeks, Bin Kişiye Düşen Banka Şube Sayısı, Bütün Ticari Bankaların Farklı Sektörlere Verdiği Krediler/GSYH, Finansal Sistemin GSYH Iç̧indeki Payı, Kredi-Mevduat Oranı olmak üzere dört ölçütü içine almakta ve bu ölçütlerin katsayıları sırasıyla $-0.277,0.931,0.923$ ve -0.207 olarak gerçekleşmektedir. Büyük oranda bankacılık sektörü ile ilgili ölçütlerin yer aldığı çalışmada kullanılan ölçütler arasında Bütün Ticari Bankaların Farklı Sektörlere Verdiği Krediler/GSYH ölçütünün endeks içerisinde diğer ölçütlere göre daha yüksek bir paya (0.931) sahip olduğu ve pozitif değer alarak endekse olumlu katkı yaptığı görülmektedir. Hindistan'da finansal derinleşmeyi inceleyen Mahajan ve Verma (2014) finansal derinleşme ölçütü olarak (Toplam Kredi + Toplam Mevduat)/GSYH, Kredi-Mevduat Oranı, M3/GSYH, Işlem Gören Hisse Senetlerinin Toplam Değeri/GSYH, Hisse Senedi Devir Hızı, Özel Sektöre Verilen Krediler/GSYH değişkenlerini temel bileşenler analizine tabi tutmuş ve bu değişkenler için sırasıyla 0.681, 0.204, 0.678, 0.629, 0.203, 0.661 katsayılarını elde etmiştir. Para ve sermaye piyasaları ile ilgili çeşitli ölçütlerin kullanıldığı çalışmada oluşturulan endeks 
içerisinde (Toplam Kredi + Toplam Mevduat)/GSYH ölçütü daha fazla ağırlığa (0.681) sahip olmuş ve pozitif değer alarak endeksi olumlu yönde etkilemiştir.

Mhadhbi (2014), 27 orta gelirli ülkede finansal derinleşmeyi incelemiş ve Banka ve Şube Sayısı, Finansal Sistemin GSYH Içindeki Yüzdesi, Finansal Sistemde Çalışan İ̧gücünün Oranı ölçütlerini kullanarak temel bileşenler analizini uygulamıştır. Analiz sonucunda Banka ve Şube Sayısı için 0.870, Finansal Sistemin GSYH İçindeki Yüzdesi için 0.930 ve Finansal Sistemde Çalışan İşgücünün Oranı için 0.810 katsayısını elde etmiştir. Ölçütlerin aldığı değerler birbirine yakın olmakla birlikte endeks içerisinde Finansal Sistemin GSYH içindeki Yüzdesi ölçütü en yüksek değerle (0.930) öne çıkmış ve endekse pozitif katkı yapmıştır.

Adnan ve Shahzad (2014) tarafından yapılan çalışmada, içinde Çek Cumhuriyeti, Yunanistan, Polonya ve Macaristan'ın da olduğu 18 Avrupa ülkesinde finansal derinleşme temel bileşenler analizi ile incelenmiştir. M3/GSYH, Mevduat Bankalarının Özel Sektöre Verdiği Krediler/GSYH, Diğer Finansal Kurumların ve Mevduat Bankalarının Özel Sektöre Verdiği Krediler/GSYH, Ticari Banka Varlıkları/ (Ticari Banka Varlıkları + Merkez Bankasının Varlıkları), Banka Yoğunlaşma Oranı, Net Faiz Oranları, Dolaylı Maliyetler, Hisse Senedi Piyasa Kapitalizasyonu/GSYH, işlem Gören Hisselerin Toplam Değeri/GSYH, Hisse Senedi Devir Hızı, Hayat Sigortası Prim Hacmi/GSYH, Hayat Dışı Sigorta Prim Hacmi /GSYH ölçütlerinin kullanıldığı çalışmada bu ölçütler sırasıyla 0.347, 0.387, 0.386, 0.207, 0.086, 0.270, 0.060, 0.328, 0.171, 0.308, 0.312, 0.276 değerlerini almıştır. Endekste kullanılan ölçütler arasında Mevduat Bankalarının Özel Sektöre Verdiği Krediler/GSYH ölçütü en yüksek değeri (0.387) alarak endekse olumlu katkı yapmıştır.

Kar ve arkadaşlar (2014) tarafından yapılan çalışmada Türkiye'de finansal derinleşme incelenmiş, M2/GSYH, Yurt Içi Krediler/GSYH, Piyasa Kapitalizasyon Oranı, Özel Sektöre Verilen Krediler/GSYH ölçütleri kullanılarak temel bileşenler analizi yapılmış ve analiz sonucunda M2/GSYH için 0.464, Yurt İçi Krediler/GSYH için 0.558, Piyasa Kapitalizasyon Oranı için 0.230 ve Özel Sektöre Verilen Krediler/GSYH için 0.648 katsayıları elde edilmiştir. Özel Sektöre Verilen Krediler/GSYH ölçütü endeks içerisinde en yüksek değeri (0.648) alarak öne çıkmış ve endeksi pozitif yönde etkilemiştir.

Varlık (2016)'ın Türkiye'de finansal derinleşmeyi incelediği çalışmada finansal derinleşmeyi temsilen Mevduatlar/GSYH, Bankaların Aktif Toplamı/GSYH, M2/GSYH, M3/GSYH, BIST100, MO/M1, Borsa Kapitalizasyon Oranı, Kredi Büyümesi ölçütleri temel bileşenler analizine tabi tutulmuş her bir değişken için 0.125 katsayısı elde edilmiştir. Bütün ölçütler endeks içerisinde eşit bir paya sahip olmuş ve endekse olumlu katkı yapmıştır.

Ak ve arkadaşları (2016) tarafından yapılan çalışmada Türkiye'de finansal derinleşme için M2, Sermaye Piyasasında İ̧̧lem Gören Hisselerin Toplam Değeri/GSYH, Özel Sektöre Verilen Krediler, Borsa İşlem Hacmi/GSYH ölçütlerine temel bileşenler analizi uygulanmış ve bu ölçütler için sırasıyla 0.940, 0.856, 0.840 ve 0.827 katsayıları elde edilmiştir. Parasal büyüklüklerden biri olan M2 ölçütü en yüksek değeri (0.940) alarak endeks içerisinde öne çıkmış ve endekse pozitif katkı yapmıştır.

Finansal derinleşme ölçütlerinin temel bileşenler analizi ile endekse dönüştürülüp ardından ekonometrik analizlerde kullanıldığı çalışmaların yanı sıra, finansal derinleşmenin kümeleme analizine tabi tutulduğu çalışmalar da bulunmaktadır.

Herrero arkadaşları (2002) tarafından yapılan çalışmada Latin Amerika ülkeleri finansal derinlik ve kişi başına milli gelir açısından hem dünya ülkeleri hem de bölge ülkeleri ile birlikte ayrı 
ayrı kümeleme analizine tabi tutulmuştur. Dünya genelinde yapılan kümeleme analizi sonuçlarına göre Latin Amerika ülkeleri finansal gelişme açısından aynı küme içerisinde yer almıştır. Bölgesel kümeleme analizine göre Latin Amerika ülkelerinin finansal sistemi gelişmekte olan Asya ülkelerinden çok küçük, gelişmekte olan Doğu Avrupa ülkelerinden ise daha az küçüktür. Latin Amerika ülkelerinin finansal sistemi Asya ülkelerinden daha çok, Doğu Avrupa ülkelerinden daha az bankacılığa dayalıdır.

Hsu ve Li (2012) tarafından yapılan çalışmada kümeleme analizi, finansal derinleşme için değil, ülkelerin OECD ve OECD dışı ülkeler ve yıllar bazında sınıflara ayrılması amacıyla yapıımıştır. Daha sonra panel veri regresyon analizi yapılmış ve sonuçta bankacılık sektöründeki finansal derinleşmenin, bankacılık dışı finansal gelişme ile üretim arasındaki fark olarak ifade edilen spekülatif yayılımı desteklediğine ve spekülatif yayılımın bankacılık sektöründeki finansal derinleşmeyi geçmesi durumunda finansal istikrarsızlık olabileceğine yönelik bulgular elde edilmiştir. Elde edilen bulgulara bağlı olarak finansal derinleşmenin bazı durumlarda ekonomik büyümeyi ve üretimi teşvik edebileceği bazı durumlarda da sınırlayabileceği vurgulanmıştır.

Gelişmekte olan ülkelerde finansal derinleşmenin temel bileşenler analizine tabi tutulması suretiyle yapılan çalışmalar oldukça fazla sayıda olmasına rağmen, finansal derinleşmenin kümeleme analizine tabi tutulduğu çalışmaların yeterli düzeyde olmadığı ifade edilebilir. Bununla birlikte finansal derinleşmenin aynı çalışmada önce temel bileşenler analizine sonra da kümeleme analizine tabi tutulduğu çalışmalar yok denecek kadar azdır. Konu ile ilgili literatürdeki bu tarz eksikliklerin giderilmesi ve literatüre katkı yapılması açısından, bu çalışmada gerçekleştirilecek uygulamanın faydalı olacağı ifade edilebilir.

\section{Araştırmanın Yöntemi ve Veri Seti}

Gelişmekte olan ülkelerin finansal derinleşme açısından sınıflandırılması amacıyla yapılan uygulama kapsamında, gelişmekte olan 17 ülkede 1997 - 2014 dönemi için yıllık veriler kullanılarak, temel bileşenler analizi ve kümeleme analizleri gerçekleştirilecektir. Bu bağlamda öncelikle çalışmada kullanılan yöntemler tanıtılacak, ardından veri seti ile ilgili bilgilendirme yapılacaktır.

\subsection{Araştırmanın Yöntemi}

Gelişmekte olan ülkelerin finansal derinleşme açısından sınıflandırılması amacıyla yöntem olarak kümeleme analizi kullanılacaktır. Ancak finansal derinleşmenin ölçülmesinde kullanılan çok sayıda ölçüt bulunduğundan, kümeleme analizinin yapılabilmesi için söz konusu ölçütlerin tek bir finansal derinleşme değişkenine indirgenmesi gerekmektedir. Bu nedenle finansal derinleşme ölçütleri temel bileşenler analizine tabi tutulacak ve elde edilen değişkenler kümeleme analizinde kullanılacaktır.

\subsubsection{Temel Bileşenler Analizi}

Temel bileşenler analizi, aralarında ilişki olan değişkenler setini, orijinal veri setine ilişkin bilginin büyük çoğunluğunu gösteren ilişkisiz değiş̧enlerden oluşan daha küçük veri setine doğrusal bir şekilde dönüştüren çok değişkenli bir istatistik yöntemidir. Temel bileşenler analizinin temeli, veri setindeki değişimleri mümkün olduğunca koruyarak, birbiriyle ilişkili çok sayıda değişkenden oluşan veri setini boyutsal olarak azaltmaya dayanmaktadır. Bunu da mevcut değişkenleri, temel bileşenler olarak adlandırılan ve birbiriyle ilişkisiz olan yeni değişkenlere dönüştürmek suretiyle gerçekleştirmektedir (Everitt ve Dunn, 2001: 48; Dunteman, 1989: 7; Landau ve Everitt, 2004: 282; Jolliffe, 2002: 1). 
Temel bileşenler analizi sonucunda ortaya çıkan bileşen sayısı, analizde kullanılan değişken sayısına eşittir. Analiz sonucunda kaç tane anlamlı bileşenin kalacağını ve yorumlanacağını belirlemek amacıyla çeşitli kriterler kullanılmaktadır. Bu kriterler aşağıdaki gibi özetlenebilir (Lehman vd., 2005: 434; Everitt ve Dunn, 2001: 53; Dunteman, 1989: 22; Pituch ve Stevens, 2015: 342):

- Özdeğer Kriteri: En yaygın kullanılan kriterlerden biri olup Kaiser - Guttman (1960) kriteri olarak da ifade edilmektedir. Bu kritere göre öz değeri 1'den büyük olan bileşenler anlamlı ve önemli bileşen olarak seçilmekte, küçük olan bileşenler yorumlamaya dahil edilmemektedir.

- Scree Testi: Cattell (1966) tarafından önerilen test, bileşenlere ilişkin öz değerleri grafik üzerinde göstermektedir. Bu testte en büyük öz değere sahip bileşenler ile en düşük öz değere sahip bileşenler arasında belirli bir kırılma noktası tespit edilmekte ve bu kırılma noktasından önceki bileşenler anlamlı ve önemli, sonrasındaki bileşenler önemsiz ve anlamsız olarak tanımlanmaktadır.

- Toplam Varyansın Yüzdesi: Toplam varyansın belirli bir oranına sahip bileşenler anlamlı ve önemli olarak, bu oranın altındaki bileşenler ise anlamsız olarak ifade edilmektedir. Bu oran bazı kaynaklarda \%70 - \%90 arasında, bazı kaynaklarda ise \%80 olarak önerilmektedir.

- Joliffe Kriteri: Öz değeri 0.7'nin altında olan bileşenler anlamsız, üzerinde olan bileşenler anlamlı ve önemli olarak ifade edilmektedir.

- Test İstatistiği: Lawley (1940) tarafından geliştirilen ve faktör sayısını istatistiksel olarak anlamlılık düzeyine göre belirleyen bir ölçüttür.

Pek çok alanda kullanılan temel bileşenler analizinin çok sayıda avantajı bulunmaktadır. Öncelikle, yöntemin boyut indirgeme özelliği, gereksiz ve istenmeyen bilgileri azaltırken, verilere ilişkin faydalı bilgileri korumaktadır. İkinci olarak analizin veri iş̧leme sürecinde kullanılan zaman ve bellek kısadır. Üçüncü olarak analizde kullanılan karmaşık veri setinin yapısının anlaşımasını ve görselleştirilmesini sağlamaktadır. Bununla birlikte, analiz yeni anlamlı temel değişkenlerin ortaya çıkarılmasını sağlamaktadır (Sanguansat, 2012: IX).

\subsubsection{Kümeleme Analizi}

Kümeleme analizi, verileri, nesneleri, birimleri vb. benzerliklerine göre sınıflandırmada kullanılan çok değişkenli istatistiksel yöntemlerden biridir. Kümeleme analizinin en temel amacı, birey veya nesnelerin temel özelliklerini dikkate almak suretiyle onları gruplandırmaktır. Kümeleme analizi, sınıflandırmaya ilaveten, hipotez testi, gerçek tiplerin belirlenmesi, gruplar için ön tahmin, aykırı değerlerin bulunması ve veriler yerine kümelerin değerlendirilmesi gibi amaçlar için de kullanılmaktadır (Uçar, 2014: 349).

Kümeleme analizi nesneleri, araştırmacı tarafından belirlenen özelliklere göre sınıflandırmaktadır. Analiz sonucunda ortaya çıkan kümeler, kendi içinde yüksek homojenlik, kendi aralarında ise yüksek heterojenlik göstermektedir. Sonuçta sınıflandırma başarılı olmuşsa, kümeler içindeki nesneler geometrik olarak işaretlendiğinde birbirine yakın, farkı kümeler ise birbirinden uzak olacaktır (Hair vd., 2010: 508).

Şekil 1.'de görüldüğü gibi kümeleme süreci hiyerarşik, hiyerarşik olmayan ve diğer olmak üzere üç sınıfa ayrılmaktadır. Hiyerarşik kümelemede hiyerarşik veya ağaca benzer bir yapı kul- 
lanılmakta olup bu kümeleme yöntemi yığmacı ve bölücü olmak üzere iki sınıfta incelenmektedir (Malhotra, 2010: 634). Yığmacı hiyerarşik yöntemler, bağlantı yöntemi, varyans yöntemi ve merkez yöntemi olmak üzere üç grupta incelenmektedir. Bu yöntemlerden bağlantı yöntemleri yaygın olarak kullanılmakta ve tek bağlantı, tam bağlantı ve ortalama bağlantı olmak üzere üç sınıfa ayrılmaktadır (Malhotra, 2010: 634).

İkinci kümeleme yöntemi olan hiyerarşik olmayan kümeleme, genellikle $k$-ortalamalar kümelemesini ifade etmektedir (Malhotra, 2010: 635). Bu yöntem, verileri araştırmacı tarafından belirtilen küme sayısına göre çeşitli gruplara ayırmaktadır (Landau ve Everitt, 2004: 311-312). Hiyerarşik olmayan kümeleme, ardışık başlama, paralel başlama ve optimum bölme olmak üzere üç sınıfa ayrılmaktadır (Malhotra, 2010: 635). Her üç yöntem de birbirine yakın sonuçlar verdiği için tek bir yöntemin kullanılması yeterli olmaktadır (Nakip, 2003: 424).

Şekil 1: Kümeleme Sürecinin Sınıflandırılması

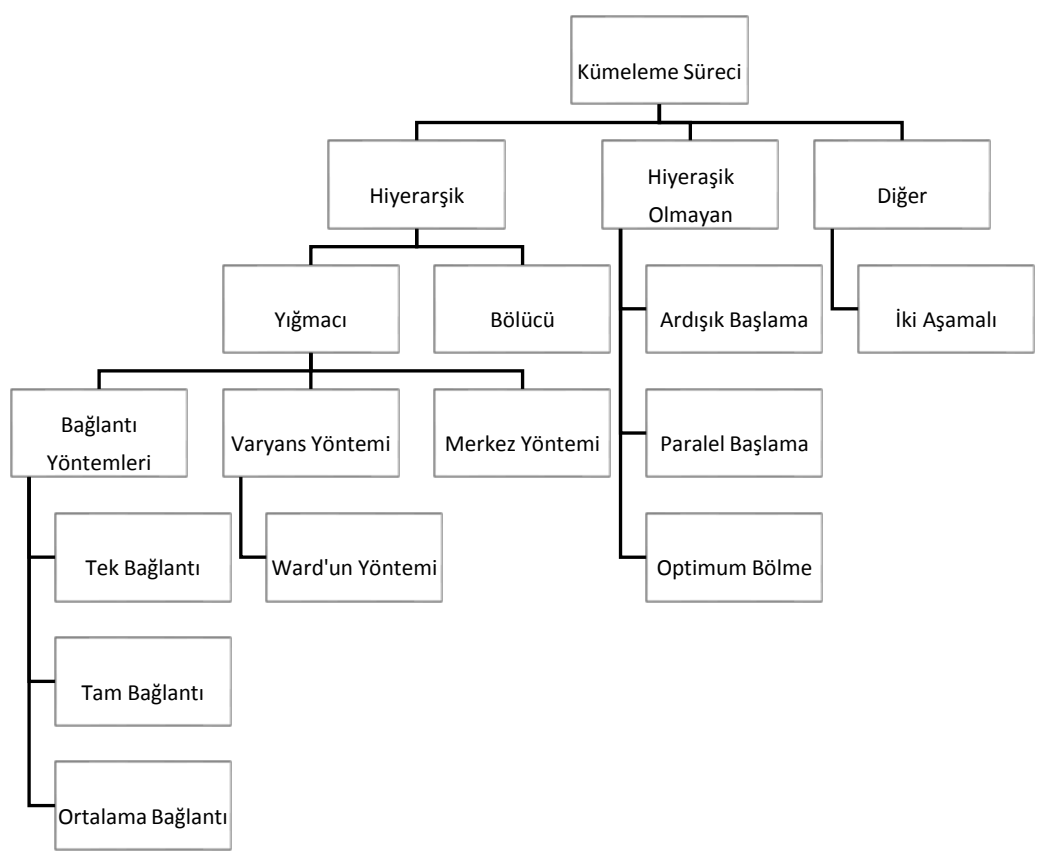

Kaynak: Malhotra, 2010: 634

Hiyerarşik olmayan kümeleme yönteminin iki önemli dezavantajı bulunmaktadır. Bunlardan birincisi küme sayısının önceden belirtilmesi, ikincisi ise küme merkezlerinin rastgele seçilmesidir. Bunun yanı sıra kümeleme sonuçları, küme merkezlerinin nasıl seçildiğine bağlı olmaktadır. Hiyerarşik olmayan kümeleme bu dezavantajlarına rağmen hiyerarşik kümelemeye göre daha hızlı sonuç vermekte ve büyük gözlemler için daha uygun olmaktadır (Malhotra, 2010: 636). Kümeleme analizinde her iki kümeleme yönteminin birlikte kullanılması önemli olup iki yöntemden hangisinin daha uygun sonuçlar verdiği karşılaştırılabilir (Nakip, 2003: 424). 


\subsection{Veri Seti}

Konu ile ilgili literatürden derlenen finansal derinleşme ölçülerinden zaman ve kaynak kısıtı nedeniyle elde edilebilen ve analize dahil edilen yıllık veriler ve uygulamanın yapılacağı ülkeler Tablo 3. ve Tablo 4.'de özetlenmektedir.

Tablo 3: Analizde Kullanılan Finansal Derinleşme Ölçütleri

\begin{tabular}{ll}
\hline \hline Ölçütün Adı & Ölçütün Simgesi \\
\hline M2/GSYH & M2 \\
M3/GSYH & M3 \\
Yurt İçi Krediler/GSYH & YiKG \\
Özel Sektöre Verilen Krediler/GSYH & OSVKG \\
Finansal Olmayan Özel Sektöre Verilen Krediler/Toplam Yurt İçi Krediler & FOSVKT \\
Finansal Olmayan Özel Sektöre Verilen Krediler/GSYH & FOSVKG \\
Özel Sektöre Verilen Krediler/Yurt İçi Kredi Hacmi & OSVKT \\
Banka Mevduatları/GSYH & BMG \\
Toplam Banka Mevduatları/GSYH & TBMG \\
Toplam Banka Varlıkları/GSYH & TBVG \\
Piyasa Kapitalizasyon Oranı & PKO \\
İşlem Gören Hisselerin Toplam Değeri/GSYH & IGHTD \\
Hisse Senedi Piyasası Devir Hızı & HPDH \\
\hline \hline
\end{tabular}

Gelişmekte olan ülkelerin çoğunda finansal sektöre ilişkin veriler finansal liberalizasyonla birlikte 80'li yılların sonundan veya 90'lı yıllardan itibaren elde edilebilmekte ve finansal derinleşmeye ilişkin daha kapsamlı veri setine 90'lı yıllardan sonra ulaşılabilmektedir. Bu nedenle 1997 - 2014 dönemi için veri elde edilebilen 17 ülkede uygulama yapılmıştır. Temel bileşenler ve kümeleme analizlerinde kullanılan ve yukarıdaki tabloda yer alan veriler IMF tarafından yayınlanan Uluslararası Finansal İstatistikler (International Financial Statistics), Dünya Bankası tarafından yayınlanan Dünya Gelişme Ölçütleri (World Development Indicator) kaynaklarından ve Datastream veri tabanından elde edilmiştir. 
Eskişehir Osmangazi Üniversitesi iỉBF Dergisi

Tablo 4: 1997-2014 Dönemi İçin Yapılacak Analizde Kullanılacak Ülke Verileri

\begin{tabular}{|c|c|c|c|c|c|c|c|c|c|c|c|c|c|}
\hline Ülke & M2 & M3 & YIKG & OSVKG & FOSVKT & FOSVKG & OSVKT & $B M G$ & TBMG & $T B V G$ & PKO & IGHTD & $\mathrm{HPDH}$ \\
\hline Arjantin & v & & v & & & v & & & & & v & & \\
\hline Brezilya & v & v & & & v & v & & & & & & v & \\
\hline Şili & v & v & v & & & & & & & & v & v & \\
\hline Çek Cumh. & v & & & & v & v & & v & & & & & \\
\hline Yunanistan & v & v & & & v & v & & & & & & v & \\
\hline Macaristan & v & v & & & v & v & & & & & & & \\
\hline Hindistan & v & & v & & v & v & & & & & & & \\
\hline Endonezya & & & & & v & & & & & & & v & v \\
\hline Ürdün & v & & v & & & & & & & & & v & \\
\hline Malezya & & & & & & & & & & & & v & v \\
\hline Meksika & & & & & v & v & & & & & v & v & \\
\hline Polonya & v & & & & & & & & & & v & $v$ & \\
\hline Rusya & & & & & V & v & & & & & & & \\
\hline Güney Afrika & v & v & & & v & v & & v & & & v & v & \\
\hline Tayland & & & & & & v & & & & & v & v & \\
\hline Türkiye & v & & & v & & & v & & v & v & v & v & \\
\hline
\end{tabular}




\section{Analiz Sonuçları ve Değerlendirme}

Gelişmekte olan 17 ülkenin 1997 - 2014 dönemi için finansal derinleşme açısından sınıflandırılması amacıyla gerçekleştirilen uygulama kapsamında, öncelikle her bir ülke için elde edilen finansal derinleşme ölçütleri temel bileşenler analizine tabi tutularak her bir ülke için finansal derinleşme temel bileşeni oluşturulmuştur. Ardından ülkelerin finansal derinleşme temel bileşenleri kümeleme analizine tabi tutularak finansal derinleşme açısından sınıflandırma yapılmıştır. Bu bağlamda öncelikle temel bileşenler analizi sonucunda elde edilen bulgular, ardından kümeleme analizi sonuçları incelenecektir.

\subsection{Temel Bileşenler Analizi Sonuçları}

Finansal derinleşme verilerinin kümeleme analizlerinde kullanılabilmesi için çok sayıda olan finansal derinleşme ölçülerinin istatistiki olarak tek bir değişkene dönüştürülmesi gerekmektedir. Bu nedenle öncelikle, 17 ülkenin (Arjantin, Brezilya, Şili, Çek Cumhuriyeti, Yunanistan, Macaristan, Hindistan, Endonezya, Ürdün, Malezya, Güney Kore, Meksika, Polonya, Rusya, Güney Afrika, Tayland ve Türkiye) 1997 - 2014 dönemine ilişkin finansal derinleşme ölçüleri temel bileşenler analizine tabi tutulmuştur. Bütün değişkenler \% cinsinden ifade edildiği ve birimleri aynı olduğu için SPSS programı ile değişkenlerin standartlaştırılmasına ihtiyaç duyulmamıştır. Veri setinin temel bileşenler analizine uygun olup olmadığı veya analizin geçerliliği Kaiser - Meyer - Olkin (KMO) ve Barlett testleri ile yapılmaktadır. KMO test değerinin \%50 ve üzerinde olması ve Barlett test istatistiğinin anlamlı olması (değişkenler arasında korelasyon olmadığını ifade eden sıfır hipotezinin reddi) temel bileşenler analizinin geçerliliği ve verinin bu analize uygunluğu için yeterli olmaktadır (Malhotra, 2010: 608). Ülkelere ilişkin finansal derinleşme temel bileşenlerinin belirlenmesinde öz değerleri birden büyük olan ve toplam varyansın büyük bir bölümüne sahip olan bileşenler dikkate alınmıştır. Temel bileşenler analizine ilişkin sonuçlar Tablo 5.'de yer almaktadır.

Tablo 5: 1997 - 2014 Dönemi Finansal Derinleşme Verilerine Iliş̧in Temel Bileşenler Analizi istatistiksel Test Sonuçları

\begin{tabular}{|c|c|c|c|c|c|c|}
\hline Ü̈lke & $\begin{array}{l}\text { Finansal Derin- } \\
\text { leşme Temel Bile- } \\
\text { şeni }\end{array}$ & KMO Testi & Barlett Testi & Öz Değer & $\begin{array}{l}\text { Toplam } \\
\text { yansın } \\
\text { desi } \\
\end{array}$ & $\begin{array}{l}\text { Var- } \\
\text { Yüz- }\end{array}$ \\
\hline Arjantin & AFD & 0.772 & $30.707(0.00)$ & 2.777 & 69.424 & \\
\hline Brezilya & BFD & 0.796 & $93.560(0.00)$ & 4.007 & 80.137 & \\
\hline Şili & ŞFD & 0.644 & $104.943(0.00)$ & 3.720 & 61.997 & \\
\hline Çek Cumhuriyeti & ÇFD & 0.602 & $89.089(0.00)$ & 2.830 & 70.757 & \\
\hline Yunanistan & YFD & 0.584 & $109.338(0.00)$ & 3.645 & 72.901 & \\
\hline Macaristan & MFD & 0.611 & $153.560(0.00)$ & 3.580 & 89.508 & \\
\hline Hindistan & HFD & 0.620 & $104.408(0.00)$ & 3.080 & 76.996 & \\
\hline Endonezya & EFD & 0.576 & $20.041(0.00)$ & 2.130 & 70.990 & \\
\hline Ürdün & ÜFD & 0.693 & $16.266(0.00)$ & 2.183 & 72.757 & \\
\hline Malezya & MAFD & 0.500 & $30.930(0.00)$ & 1.930 & 96.477 & \\
\hline Güney Kore & GKFD & 0.544 & $99.744(0.00)$ & 3.240 & 81.002 & \\
\hline Meksika & MEFD & 0.676 & $38.391(0.00)$ & 2.798 & 69.942 & \\
\hline Polonya & PFD & 0.674 & $28.426(0.00)$ & 2.385 & 79.515 & \\
\hline Rusya & RFD & 0.500 & $12.229(0.00)$ & 1.739 & 86.935 & \\
\hline Güney Afrika & GAFD & 0.808 & $251.741(0.00)$ & 5.644 & 80.633 & \\
\hline Tayland & TAFD & 0.608 & $30.555(0.00)$ & 2.252 & 75.072 & \\
\hline Türkiye & TFD & 0.705 & $191.753(0.00)$ & 5.064 & 72.349 & \\
\hline
\end{tabular}


Tablo 5. incelendiğinde, bütün ülkeler için hesaplanan KMO test değerinin \%50'nin üzerinde olduğu ve Barlett test istatistiklerinin anlamlı olduğu görülmektedir. Dolayısıyla bütün ülkelerin finansal derinleşme verilerinin temel bileşenler analizi için uygun olduğu ifade edilebilir. Ülkelerin finansal derinleşme bileşenlerine ilişkin öz değerler incelendiğinde, hepsinin birden büyük ve yüksek düzeylerde olduğu söylenebilir. Bunun yanı sıra bütün ülkelerde finansal derinleşme temel bileşenlerinin varyanslarının, toplam varyansın büyük çoğunluğuna sahip olduğu, \%62 96 aralığında dalgalandığı ve söz konusu temel bileşenlerin hem özdeğer bir, hem de toplam varyansın yüzdesi kriterlerine uygun olarak belirlendiği ifade edilebilir.

Tablo 6.' da temel bileşenler analizine dahil edilen ülkelerin finansal derinleşme bileşenlerine ilişkin bileşen skor katsayıları verilmektedir. Tablo 6.'da yer alan sonuçlara göre ülkelere ilişkin finansal derinleşme temel değişkenleri aşağıdaki gibi formüle edilebilir:

$$
\begin{aligned}
& A F D=0.305 * \mathrm{M} 2+0.315 * \mathrm{M} 3+0.332 \mathrm{YiKG}+0.240 * \mathrm{FOSVKT} \\
& B F D=0.240 * M 2+0.231 * M 3+0.216 * F O S V K T+0.228 * F O S V K G+0.200 * i G H T D \\
& S F D=-0.251 * M 2-0.125 * M 3+0.056 * Y i K G+0.262 * P K O+0.260 * i G H T D \\
& \text { ÇFD }=0.538 * \mathrm{M} 2-0.235 * \text { FOSVKT }-0.010 * \text { FOSVKG }+0.520 * B M G \\
& Y F D=0.267 * M 2+0.260 * M 3+0.250 * F O S V K T+0.215 * F O S V K G-0.164 * i G H T D \\
& M F D=0.277 * M 2+0.278 * M 3-0.234 * F O S V K T+0.266 * F O S V K G \\
& H F D=0.315 * M 2+0.318 * \text { YiKG }-0.142 * F O S V K T+0.322 \text { FOSVKG } \\
& E F D=0.327 * F O S V K T+0.413 * i G H T D+0.438 * H P D H \\
& \ddot{U} F D=0.403 * M 2+0.402 * \text { YiKG }+0.366 * i G H T D \\
& \text { MEFD }=0.266 * F O S V K T+0.306 * F O S V K G+0.298 * P K O+0.323 * i G H T D \\
& P F D=0.338 * M 3+0.392 * P K O+0.389 * i G H T D \\
& R F D=0.536^{*} F O S V K T+0.536^{*} F O S V K G \\
& \text { GAFD }=0.171^{*} M 2+0.171^{*} M 3+0.129 * F O S V K T+0.153^{*} F O S V K G+0.171^{*} B M G+ \\
& 0.152 * P K O+0.163 * i G H T D \\
& \text { TAFD }=-0.309 * \text { FOSVKG }+0.417 * P K O+0.418 * i G H T D \\
& T F D=0.191 * M 2+0.237 * \text { OSVKG }+0.232 * T B M G-0.162 * \text { OSVKT }+0.239 * T B V G-0.189 * P K O \\
& -0.013 * i G H T D
\end{aligned}
$$

Gelişmekte olan 17 ülkede finansal derinleşme ile ilgili temel bileşenler analizi sonucu elde edilen skor katsayıları incelendiğinde, beşülkede (Arjantin, Hindistan, Rusya, Güney Afrika, Türkiye) bankacılık sektörüne, altı ülkede (Brezilya, Çek Cumhuriyeti, Yunanistan, Macaristan, Ürdün, Güney Afrika) para arzına, yedi ülkede (Şili, Endonezya, Malezya, Güney Kore, Meksika, Polonya, Tayland) menkul kıymet piyasalarına ilişkin finansal derinleşme ölçütlerinin finansal derinleşme temel bileşenleri içerisinde daha fazla ağırlığa sahip olduğu görülmektedir.

Temel bileşenler analiz sonuçları, konu ile ilgili literatürde yapılan çalışmalarla karşılaştırıldığında kullanılan değişkenler ve bulunan skor katsayıları açısından bazı benzerlik ve farklıııkların olduğu görülmektedir. Karşılaştırma açısından literatürde kullanılan ölçütlere benzer ölçütlerle ilgili açıklama yapılmıştır. 
Ağustos 2019, C. 14, S. 2

Tablo 6: Finansal Derinleşme Temel Bileşenlerinin Skor Katsayıları

\begin{tabular}{|c|c|c|c|c|c|c|c|c|c|c|c|c|c|}
\hline $\begin{array}{l}\text { FINDER } \\
\text { Temel Bi- } \\
\text { leşeni }\end{array}$ & $\mathrm{M} 2$ & M3 & YiKG & OSVKG & FOSVKT & FOSVKG & OSVKT & BMG & TBMG & TBVG & PKO & İGHTD & $\mathrm{HPDH}$ \\
\hline BFD & 0.240 & 0.231 & & & 0.216 & 0.228 & & & & & & 0.200 & \\
\hline ŞFD & -0.251 & -0.125 & 0.056 & & & & & & & & 0.262 & 0.260 & \\
\hline YFD & 0.267 & 0.260 & & & 0.250 & 0.215 & & & & & & -0.164 & \\
\hline MFD & 0.277 & 0.278 & & & -0.234 & 0.266 & & & & & & & \\
\hline HFD & 0.315 & & 0.318 & & -0.142 & 0.322 & & & & & & & \\
\hline EFD & & & & & 0.327 & & & & & & & 0.413 & 0.438 \\
\hline ÜFD & 0.403 & & 0.402 & & & & & & & & & 0.366 & \\
\hline GKFD & 0.290 & 0.287 & & & & & & & & & 0.238 & 0.292 & \\
\hline MEFD & & & & & 0.266 & 0.306 & & & & & 0.298 & 0.323 & \\
\hline PFD & & 0.338 & & & & & & & & & 0.392 & 0.389 & \\
\hline RFD & & & & & 0.536 & 0.536 & & & & & & & \\
\hline GAFD & 0.171 & 0.171 & & & 0.129 & 0.153 & & 0.171 & & & 0.152 & 0.163 & \\
\hline TAFD & & & & & & -0.309 & & & & & 0.417 & 0.418 & \\
\hline TFD & 0.191 & & & 0.237 & & & -0.162 & & 0.232 & 0.239 & -0.189 & -0.013 & \\
\hline
\end{tabular}


Hussain (2012) tarafından yapılan çalışmada Hindistan için kullanılan ölçütlerden biri olan Bütün Ticari Bankaların Farklı Sektörlere Verdiği Krediler/GSYH ölçütü ve Mahajan ve Verma (2014) tarafından Hindistan için kullanılan Özel Sektöre Verilen Krediler/GSYH ölçütleri sırasıyla 0.931 ve 0.661 katsayılarını almış olup bu çalışmada Hindistan için kredilere ilişkin olarak gerçekleşen finansal derinleşme ölçütünden (0.322) yüksek bir değer almıştır.

Gries ve arkadaşları (2009)'nın yaptığı çalışmada Güney Afrika için M3/GSYH ve Mevduat Bankalarının Özel Sektöre Verdiği Krediler/GSYH ölçütleri sırasıyla -0.674 ve 0.846, Zerbo (2015) tarafından yapılan çalışmada Güney Afrika için M2/GSYH ölçütü 0.534, Özel Sektöre Verilen Krediler/GSYH ölçütü 0.594 ve Kitenge (2013)'nin yaptığı çalışmada Güney Afrika için M3/GSYH ölçütü 0.524 katsayılarını almıştır.

Adnan ve Shahzad (2014) tarafından Çek Cumhuriyeti, Yunanistan, Polonya ve Macaristan'ın da olduğu 18 Avrupa ülkesinde M3/GSYH, Mevduat Bankalarının Özel Sektöre Verdiği Krediler/GSYH, Hisse Senedi Piyasa Kapitalizasyonu/GSYH, İşlem Gören Hisselerin Toplam Değeri/GSYH ölçütleri temel bileşenler analizi sonunda sırasıyla 0.347, 0.387, 0.328, 0.171 değerlerini almıştır. Bu değerlerden M3/GSYH ölçütü, bu çalışmada Polonya, Yunanistan ve Macaristan için bulunan katsayılara yakın bir değer, Mevduat Bankalarının Özel Sektöre Verdiği Krediler/GSYH ölçütü, Yunanistan ve Macaristan için kullanılan benzer ölçütün katsayılarına yakın değerler alırken, Çek Cumhuriyeti'nin katsayısından farklı bir değer almıştır. Hisse Senedi Piyasa Kapitalizasyonu/GSYH ve İşlem Gören Hisselerin Toplam Değeri ölçütleri bu çalışmada Polonya için elde edilen katsayılara yakın değerler alırken, Yunanistan'ın katsayısı oldukça farklı bir değer almıştır.

Türkiye için bu çalışmada elde edilen M2 ölçütünün katsayısı Kar ve ark.(2014) tarafından elde edilen değerden (0.464) düşük, Varlık (2016) tarafından bulunan değere (0.125) yakın değerler almıştır. Türkiye'nin YíkG katsayısı, Kar ve arkadaşları (2014) tarafından elde edilen değerden (0.558) düşük olarak gerçekleşmiştir. TBMG ve TBVG ölçütlerinin bu çalışmada Türkiye için gerçekleşen değerleri, Varlık (2016) tarafından yapılan çalışmada elde edilen değerlerden (0.125) daha yüksektir. Türkiye için elde edilen PKO ölçütünün değeri negatif olup Kar ve arkadaşları (2014)'nın ve Varlık (2016)'ın elde ettiği değerlerden (sırasıyla 0.230 ve 0.125 ) daha düşüktür. IGHTD ölçütünün bu çalışmada bulunan katsayısı, Ak ve arkadaşları (2016)'nın elde ettiği değerden (0.856) düşük bir değer almıştır.

Uygulama kapsamında finansal derinleşmeye ilişkin olarak gerçekleştirilen temel bileşenler analizi sonucunda elde edilen temel bileşen skor katsayıları, ilgili literatürde elde edilen bazı katsayılardan yüksek, bazılarından düşük ve bazılarına ise yakın değerler almış olup literatürdeki bazı çalışmaların sonuçları ile uyumludur. Katsayı farklılıkları, ülke bazında temel bileşenler analizine katılan ölçütlerin, uygulama dönemlerinin ve kullanılan veri frekanslarının farklı olmasından kaynaklanmış olabilmektedir.

\subsection{Kümeleme Analizi Sonuçları}

Temel bileşenler analizi sonucunda 17 ülke için elde edilen finansal derinleşme temel bileşenleri hiyerarşik kümeleme analizine tabi tutulmuş ve yığılma tablosu ve dendogramda yer alan sonuçlar elde edilmiştir.

Yığılma tablosunda, kümeleme aşamaları, birleştirilen kümeler, gözlemler arasındaki mesafeyi gösteren katsayılar (kareli öklit uzaklığı), kümenin ilk görüldüğü aşama (bir kümenin hangi aşamada şekillendiği) ve sonraki aşama (o satırdaki iki gözlemin hangi aşamada bir diğer gözlemle birleşerek küme haline geldiği aşama) yer almaktadır (Uçar, 2014: 367). 
Tablo 7: Kümeleme Analizi Yığılma Tablosu

\begin{tabular}{|c|c|c|c|c|c|c|}
\hline \multirow[t]{2}{*}{ Aşama } & \multicolumn{2}{|c|}{ "Birleştirilen Kümeler } & \multirow[t]{2}{*}{ Katsayılar } & \multicolumn{2}{|c|}{ Kümenin IIlk Görüldüğü Aşama } & \multirow[t]{2}{*}{ Sonraki Aşama } \\
\hline & Küme 1 & Küme 2 & & Küme 1 & Küme 2 & \\
\hline 1 & 6 & 7 & 0.308 & 0 & 0 & 2 \\
\hline 2 & 6 & 14 & 0.858 & 1 & 0 & 3 \\
\hline 3 & 5 & 6 & 1.486 & 0 & 2 & 6 \\
\hline 4 & 11 & 15 & 2.267 & 0 & 0 & 7 \\
\hline 5 & 4 & 17 & 3.223 & 0 & 0 & 8 \\
\hline 6 & 2 & 5 & 4.576 & 0 & 3 & 8 \\
\hline 7 & 11 & 13 & 6.187 & 4 & 0 & 10 \\
\hline 8 & 2 & 4 & 8.771 & 6 & 5 & 12 \\
\hline 9 & 3 & 9 & 12.211 & 0 & 0 & 11 \\
\hline 10 & 11 & 16 & 17.520 & 7 & 0 & 12 \\
\hline 11 & 3 & 8 & 23.501 & 9 & 0 & 14 \\
\hline 12 & 2 & 11 & 29.580 & 8 & 10 & 14 \\
\hline 13 & 10 & 12 & 38.930 & 0 & 0 & 15 \\
\hline 14 & 2 & 3 & 59.315 & 12 & 11 & 16 \\
\hline 15 & 1 & 10 & 87.293 & 0 & 13 & 16 \\
\hline 16 & 1 & 2 & 140.489 & 15 & 14 & 0 \\
\hline
\end{tabular}

Tablo 7.'de yer alan kümeleme analizinin yığılma tablosu incelendiğinde, sürecin 16 aşamadan oluştuğu görülmektedir. Kümeleme analizinin birinci aşamasında, Küme 1'de 6. gözlem (Macaristan) ile Küme 2' de 7. gözlem (Hindistan) finansal derinleşme açısından birbirine en benzer iki ülke olarak konumlanmış ve aralarındaki mesafe 0.308 olarak gerçekleşmiştir. Macaristan ve Hindistan 2. aşamada aralarına 14. gözlem olan Rusya'yı alarak ilk kümeyi oluşturmuşlardır.

İkinci aşamanın devamında "Sonraki Aşama" sütununda yer alan 3 rakamı üçüncü aşamada, birinci kümeye yeni bir gözlemin katılarak yeni bir küme oluşturacağını belirtmektedir. Bu bağlamda ikinci aşamada birleşen Macaristan ve Rusya'nın, üçüncü aşamada Yunanistan'ı (5. Gözlemi) aralarına alarak ikinci kümeyi oluşturdukları görülmektedir. Üçüncü aşamada Yunanistan ile birleşen Macaristan, altıncı aşamada 2. gözlem olan Brezilya ile birleşerek üçüncü kümeyi meydana getirmiştir.

Dördüncü aşamada Güney Kore (11. Gözlem) ile Güney Afrika(15. Gözlem) birleşmiş olup aralarındaki mesafe 2.267 şeklinde gerçekleşmiştir. Dördüncü aşamada Güney Afrika ile birleşen Güney Kore'ye, yedinci aşamada Polonya(13. Gözlem) katılmış ve bu şekilde dördüncü küme oluşmuştur.

Beşinci aşamada Çek Cumhuriyeti (4. Gözlem) ile Türkiye (17 gözlem) birleşmiş olup aralarındaki mesafe 3.223 olarak gerçekleşmiştir. Çek Cumhuriyeti ve Türkiye, sekizinci aşamada Brezilya'yı da kendi gruplarına dahil ederek altıncı kümeyi oluşturmuşlardır.

Altıncı aşamada Macaristan ile Brezilya birleşmiş ve aralarındaki mesafe 4.576 olarak gerçekleşmiştir. Bu aşamada Macaristan ile birleşen Brezilya, sekizinci aşamada Çek Cumhuriyeti ile birleşerek beşinci kümeyi meydana getirmiştir.

Yedinci aşamada Güney Kore (11. Gözlem) ile Polonya (13. gözlem) birleşmiş olup aralarındaki uzaklık 6.187 olarak gerçekleşmiştir. Bu aşamada Polonya ile birleşen Güney Kore'ye onuncu aşamada Tayland (16. Gözlem) katılmış ve bu şekilde yedinci küme oluşmuştur.

Dokuzuncu aşamada Şili (3. Gözlem) ile Ürdün (9. Gözlem) birleşmiş olup aralarındaki mesafe 12.211 olarak gerçekleşmiştir. Şili ve Ürdün'e on birinci aşamada Endonezya (8. Gözlem) katılmış ve dokuzuncu küme meydana gelmiştir. 
Sekizinci aşamada oluşan hem altıncı hem de beşinci kümenin elemanı olan Brezilya (2. Gözlem), on ikinci aşamada Güney Kore (11. Gözlem) ile birleşerek sekizinci kümeyi, oluşturmuştur. Aynı zamanda on ikinci aşamada, onuncu aşamada birleşen Güney Kore ve Tayland'a Brezilya'nın katılmasıyla onuncu kümenin oluştuğu da görülmektedir.

On üçüncü aşamada Malezya (10. Gözlem) ile Meksika (12. Gözlem)birleşmiş olup aralarındaki uzaklık 38.930 olarak gerçekleşmiştir. Malezya ve Meksika'ya on beşinci aşamada Arjantin (1. Gözlem) katılmış ve bu şekilde on üçüncü küme meydana gelmiştir.

On birinci aşamada Endonezya ile birleşen Şili, on dördüncü aşamada Brezilya ile birleşerek on ikinci kümeyi oluşturmuştur. Aynı zamanda, on ikinci aşamada birleşen Brezilya ve Güney Kore'ye on dördüncü aşamada Şili'nin katılmasıyla on birinci küme de oluşmuştur.

On dördüncü aşamada birleşen Brezilya ve Şili'ye on altıncı aşamada Arjantin'in (1. Gözlem) katılmasıyla on beşinci küme meydana gelmiştir. Bununla birlikte on beşinci aşamada birleşen Arjantin ve Malezya (10. Gözlem), on altıncı aşamada aralarına Brezilya'yı da alarak on dördüncü kümeyi oluşturmuştur. 16. aşamaya gelinceye kadar tüm aşamalar bu şekilde devam etmiş ve 16. aşamada aralarında en uzak mesafe olan Arjantin ve Brezilya da birleşerek tüm gözlemler tek bir kümeye dahil olmuştur.

Aralarındaki kareli öklit uzaklığı dikkate alındığında, birbirine en yakın ülkeler Macaristan (6. gözlem) ve Hindistan (7. gözlem) olup aralarındaki mesafe 0,308, en uzak ülkeler ise Arjantin (1. gözlem) ve Brezilya (2. gözlem) olup aralarındaki mesafe 140.489 'dur. Başka bir deyişle, finansal derinleşme açısından birbirine en çok benzeyen ülkeler Macaristan ve Hindistan olurken, birbirine en az benzeyen ülkeler ise Arjantin ve Brezilya olmuştur.

Şekil 2: Kümeleme Analizi Ağaç Grafiği (Dendogram)

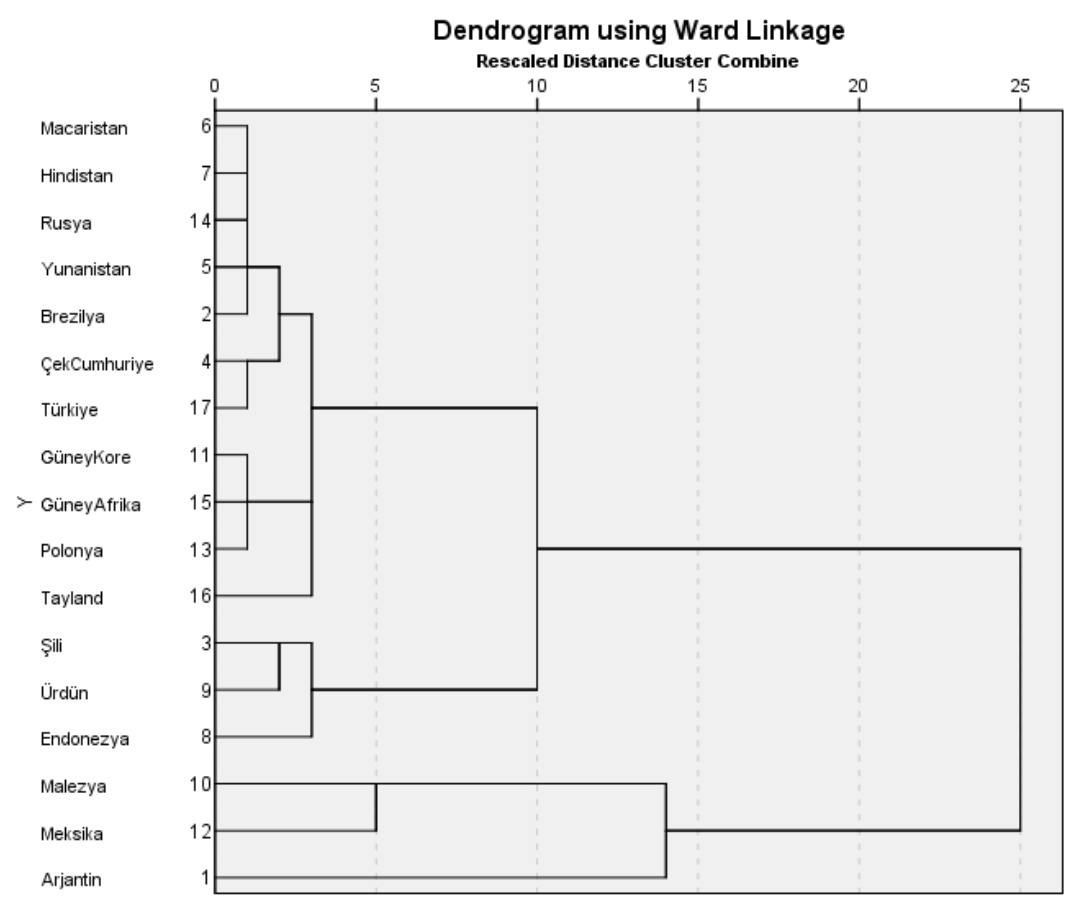


Dendogramda yatay eksen yeniden ölçeklenmiş bağlantı uzaklıklarını, dikey eksen ise ülkeleri (birleşen kümeleri) göstermektedir. Dendogramda sağa doğru gidildikçe, birbirine mesafesi daha az olan daha çok sayıda ülkeyi içine alacak şekilde yeni kümelerin oluştuğu görülmektedir (Öz vd., 2009, 16). Dendogram incelendiğinde, gözlemlerin genel olarak 4 kümeye (6-----16), (3---8), (10----12) ve (1) ayrıldığı ve bu kümelerde sırasıyla 11, 3, 2 ve 1 gözlem bulunduğu görülmektedir.

Dendogramdan elde edilen bulgular göz önünde bulundurularak küme sayısının dört olması gerektiğine karar verilmiştir. Kümeleme analizi sonucunda oluşan birinci kümede Brezilya, Çek Cumhuriyeti, Yunanistan, Macaristan, Hindistan, Güney Kore, Polonya, Rusya, Güney Afrika, Tayland ve Türkiye olmak üzere 11 ülke, ikinci kümede Şili, Ürdün ve Endonezya, olmak üzere 3 ülke, üçüncü kümede Meksika ve Malezya olmak üzere 2 ülke ve dördüncü kümede bir ülke (Arjantin) yer almaktadır.

Tablo 8: Ülke Sınıflandırmalarının Karşılaştırılması

\begin{tabular}{|c|c|c|}
\hline Kümeleme Analizi & Dünya Bankası & $\mathrm{IMF}$ \\
\hline \multicolumn{3}{|c|}{ 1. Küme } \\
\hline Çek Cumhuriyeti & Yüksek gelirli & Gelişmekte Olan ve Gelişen Avrupa \\
\hline Yunanistan & Yüksek gelirli & Gelişmekte Olan ve Gelişen Avrupa \\
\hline Macaristan & Yüksek gelirli & Gelişmekte Olan ve Gelişen Avrupa \\
\hline Polonya & Yüksek gelirli & Gelişmekte Olan ve Gelişen Avrupa \\
\hline Güney Kore & Yüksek gelirli & Gelişmekte Olan ve Gelişen Asya \\
\hline Brezilya & Yüksek-orta gelirli & Latin Amerika ve Karayipler \\
\hline Rusya & Yüksek-orta gelirli & Bağımsız Devletler Topluluğu \\
\hline Tayland & Yüksek-orta gelirli & Gelişmekte Olan ve Gelişen Asya \\
\hline Türkiye & Yüksek-orta gelirli & Gelişmekte Olan ve Gelişen Avrupa \\
\hline Hindistan & Düşük-orta gelirli & Gelişmekte Olan ve Gelişen Asya \\
\hline Güney Afrika & Yüksek-orta gelirli & Sahraaltı Afrika \\
\hline \multicolumn{3}{|c|}{ 2. Küme } \\
\hline Şili & Yüksek gelirli & Latin Amerika ve Karayipler \\
\hline Ürdün & Yüksek-orta gelirli & Ortadoğu, Kuzey Afrika ve Pakistan \\
\hline Endonezya & Düşük-orta gelirli & Gelişmekte Olan ve Gelişen Asya \\
\hline \multicolumn{3}{|c|}{ 3. Küme } \\
\hline Meksika & Yüksek-orta gelirli & Latin Amerika ve Karayipler \\
\hline Malezya & Yüksek-orta gelirli & Gelişmekte Olan ve Gelişen Asya \\
\hline \multicolumn{3}{|c|}{ 4. Küme } \\
\hline Arjantin & Yüksek gelirli & Latin Amerika ve Karayipler \\
\hline
\end{tabular}

Tablo 8. incelendiğinde finansal derinleşme açısından benzer özellikler gösteren ve birinci kümeye yerleşen ülkelerden bazıları, hem Dünya Bankası, hem de IMF tarafından yapılan sınıflandırmalarda aynı grubu paylaşmakta (Çek Cumhuriyeti, Yunanistan, Macaristan ve Polonya), bazıları (Brezilya, Rusya, Tayland, Türkiye, Güney Afrika) sadece Dünya Bankası sınıflandırmaları açısından benzeşmekte, bazıları ise (Güney Kore, Hindistan, Tayland) sadece IMF sınıflandırmasına göre aynı kümede yer almaktadır. Finansal derinleşme kümelemesinde ikinci kümede yer alan Şili, Ürdün ve Endonezya, sadece finansal derinleşme açısından ortak özellikler göstermekte, diğer sınıflandırmalar açısından farklı gruplarda yer almaktadır. Üçüncü kümede yer alan Meksika ve Malezya hem finansal derinleşme, hem de kişi başına düşen milli gelir açısından benzer özellikler göstermektedir. Dünya Bankası sınıflandırmasına göre yüksek gelirli, IMF sınıflandırmasına göre Latin Amerika ve Karayipler sınıfında yer alan Arjantin finansal derinleşme açısından diğer ülkelerden tamamen farklı özelliklere sahip olup tek başına dördüncü kümeyi oluşturmaktadır. 
Kümeleme analizinde incelenen gelişmekte olan 17 ülkenin, analiz sonucunda oluşturduğu dört küme incelendiğinde, kümeler içerisinde daha önce Dünya Bankası ve IMF tarafından yapılan ülke sınıflandırmalarında aynı grup içerisinde yer alan bazı ülkelerin, finansal derinleşme açısından da aynı küme içerisinde yer aldığı, bazı ülkelerin de söz konusu sınıflandırmalardan farklı hareket ettiği görülmektedir. Aynı kümede yer alan ve finansal derinleşme açısından benzeşen bazı ülkelerin, coğrafi konum ve kişi başına düşen milli gelir açısından benzeşmeleri, söz konusu ülkelerin finansal derinleşme açısından da aynı kümede yer almasını desteklemiş olabilir. Bununla birlikte finansal derinleşme açısından benzeyen ülkeler için temel bileşenler analizi ile hesaplanan finansal derinleşme endekslerinin benzer ölçütlerden oluşmasının da bu ülkelerin aynı kümede yer almasına katkı sağlamış olması mümkündür.

\section{Sonuç}

Gelişmekte olan ülkelerde finansal sistemin işleyişini ve gelişimini daha iyi anlayabilmek, ülkelerin finansal derinleşme açısından benzerlik ve farklılıklarını tespit edebilmek, ülkelerin finansal derinleşme açısından kendilerini tanıyabilmeleri ve ülkeler arasında konumlandırabilmeleri açısından oldukça önemlidir. Bu kapsamda ulusal ve uluslararası literatüre önemli katkılar sağlayabileceği düşünülen çalışmanın amacı, gelişmekte olan hangi ülkelerin finansal derinleşme açısından farklı, hangilerinin benzer özellikler gösterdiğini belirlemektir. Çalışmanın amacı, yöntem olarak temel bileşenler analizi ve kümeleme analizi kullanmak suretiyle 1997 2014 dönemi için veri elde edilebilen 17 ülkede uygulama yapılarak gerçekleştirilmeye çalışımıştır.

Gelişmekte olan ülkelerde finansal derinleşme incelenirken, finansal derinleşmenin daha iyi temsil edilebilmesi için çeşitli ölçütler kullanılmaktadır. Bu ölçütler bankacılık sektörüne, parasal duruma, sermaye piyasasına, finansal sisteme ilişkin olabilmekte ve genellikle temel bileşenler analizi kullanılarak tek bir bileşene indirgenmektedir. Bu süreç çalışmada da izlenmiş ve her bir ülke için literatürde kullanılan finansal derinleşme ölçütleri elde edilerek temel bileşenler analizine tabi tutulmuştur. Temel bileşenler analizi kapsamında elde edilen 17 ülkenin her biri için hem özdeğer bir, hem de toplam varyansın yüzdesi kriterlerine uygun olarak temel bileşenler belirlenmiştir. Gelişmekte olan 17 ülkede finansal derinleşme ile ilgili temel bileşenler analizi sonucu elde edilen skor katsayıları, beş ülkede (Arjantin, Hindistan, Rusya, Güney Afrika, Türkiye) bankacılık sektörüne, altı ülkede (Brezilya, Çek Cumhuriyeti, Yunanistan, Macaristan, Ürdün, Güney Afrika) para arzına, yedi ülkede (Şili, Endonezya, Malezya, Güney Kore, Meksika, Polonya, Tayland) menkul kıymet piyasalarına ilişkin finansal derinleşme ölçütlerinin finansal derinleşme temel bileşenleri içerisinde daha fazla ağırlığa sahip olduğunu göstermektedir. ÇaIışmada finansal derinleşmeye ilişkin olarak gerçekleştirilen temel bileşenler analizi sonucunda elde edilen temel bileşen skor katsayıları, ilgili literatürde elde edilen bazı katsayılardan yüksek, bazılarından düşük ve bazılarına ise yakın değerler almış olup literatürdeki bazı çalışmaların sonuçları ile uyumludur. Katsayı farklılıkları, ülke bazında temel bileşenler analizine katılan ölçütlerin, uygulama dönemlerinin ve kullanılan veri frekanslarının farklı olmasından kaynaklanmış olabilmektedir.

Temel bileşenler analizi sonucunda 17 ülke için elde edilen finansal derinleşme temel bileşenleri hiyerarşik kümeleme analizine tabi tutulmuştur. Dendogramdan elde edilen bulgular göz önünde bulundurularak küme sayısının dört olması gerektiğine karar verilmiştir. Kümeleme analizi sonucunda oluşan birinci kümede Brezilya, Çek Cumhuriyeti, Yunanistan, Macaristan, Hindistan, Güney Kore, Polonya, Rusya, Güney Afrika, Tayland ve Türkiye olmak üzere 11 ülke, 
ikinci kümede Şili, Ürdün ve Endonezya, olmak üzere 3 ülke, üçüncü kümede Meksika ve Malezya olmak üzere 2 ülke ve dördüncü kümede bir ülke (Arjantin) yer almaktadır.

Kümeleme analizinde incelenen gelişmekte olan 17 ülkenin, analiz sonucunda oluşturduğu dört küme incelendiğinde, kümeler içerisinde daha önce Dünya Bankası ve IMF tarafından yapılan ülke sınıflandırmalarında aynı grup içerisinde yer alan bazı ülkelerin, finansal derinleşme açısından da aynı küme içerisinde yer aldığı, bazı ülkelerin de söz konusu sınıflandırmalardan farklı hareket ettiği görülmektedir. Aynı kümede yer alan ve finansal derinleşme açısından benzeşen bazı ülkelerin, coğrafi konum ve kişi başına düşen milli gelir açısından benzeşmeleri, söz konusu ülkelerin finansal derinleşme açısından da aynı kümede yer almasını desteklemiş olabilir. Bununla birlikte finansal derinleşme açısından benzeyen ülkeler için temel bileşenler analizi ile hesaplanan finansal derinleşme endekslerinin benzer ölçütlerden oluşmasının da bu ülkelerin aynı kümede yer almasına katkı sağlamış olması mümkündür.

Temel bileşenler analizi sonucunda elde edilen bulgular, finansal derinleşme düzeyinin yükseltilmesinde politika yapıcıların hangi ölçütlere odaklanması gerektiğine ilişkin olarak uygulayacakları politikaları belirlemeleri açısından yol gösterici olabilir. Bununla birlikte kümeleme analizi ile elde edilen bulgular, finansal derinleşme açısından benzeyen aynı zamanda IMF ve/veya Dünya Bankası sınıflandırmalarında da aynı kümede yer alan ülkelerde finansal derinleşmeyi destekleyecek benzer ekonomik politikaların uygulanarak ülkeler açısından karşılaştırma yapma imkanı sağlayabilir. İleride yapılacak çalışmalar açısından daha geniş bir zaman aralığı dikkate alınarak, daha çok sayıda ülkeyi kapsayacak şekilde ve finansal derinleşme ölçütlerinin endekse dönüştürülmeden ayrı ayrı incelenmesi suretiyle yapılacak analizler finansal derinleşme açısından ülkelerin daha detaylı bir şekilde incelenmesini sağlayabilir. 


\section{Eskişehir Osmangazi Üniversitesi IïB Dergisi}

\section{Kaynaklar}

Abu-Bader, Suleiman; Abu-Qarn, Aamer S. (2008), "Financial Development and Economic Growth: The Egyptian Experience", Journal of Policy Modeling, Vol. 30, No. 5: 887-898.

Adnan, Noureen; Shahzad, Syed Jawad Hussain (2014), "The European Financial System in Limelight",http://mpra.ub.uni-muenchen.de/60152/, (Erişim: 15.01.2016).

Adu, George; Marbuah, George; Mensah, Justice Tei (2013), "Financial Development and Economic Growth in Ghana:Does The Measure of Financial Development Matter?", Review of Development Finance, Vol. 3, No. 4 :192203.

Ağır, Hüseyin (2010), Türkiye'de Finansal Liberalizasyon ve Finansal Derinleşme Iilişkisinin Ekonometrik Analizi, Ankara:BDDK Kitapları, https://www.bddk.org.tr/WebSitesi/turkce/Raporlar/Kitaplar/8639agir_.pdf, (Erişim:20.01.2015).

Ak, Mehmet Zeki; Altıntaş, Nurullah; Şimşek, Ahmet Salih (2016), "Türkiye'de Finansal Gelişme Ve Ekonomik Büyüme Ilişkisinin Nedensellik Analizi”, Doğuş Üniversitesi Dergisi, C. 17, S. 2: 151-160.

Ali, Rafaget (2014), "The Role of Bank Based Finance in Economic Growth of Pakistan”, Middle -East Journal of Scietific Research, Vol. 22, No. 1: 82-90.

Ang, James B.; McKibbin, Warwick J. (2007), “Financial Liberalization Financial Development and Growth: Evidence From Malaysia", Journal of Developments Economics, Vol. 84, No. 1: 215-233.

Akinboade, Oludele Akinloye; Kinfack, Emilie Chanceline (2013), “Interest Rate Reform Financial Deepening and Economic Growth in Cameroon: An Ampirical Investigation", Applied Economics, Vol. 45, No. 25: $3574 \quad-3586$.

Demirgüç - Kunt, Aslı; Levine, Ross (1996), "Stock Market Development and Financial İntermediaries: Stylized Facts", The World Bank Economic Review, Vol. 10, No. 2: 291-321.

Demirgüç - Kunt, Aslı; Maksimoviç, Vojislav (1996), "Stock Market Development Financing Choices of Firms", The World Bank Economic Review, Vol. 10, No. 2: 341-369.

Dunteman, George H. (1989), Principal Components Analysis. Quantitative Applications in The Social Sciences. USA: Sage Publications.

Erdem, Havvanur Feyza; Yamak, Rahmi (2014), "The Dynamic Relationship Between Economics and Financial Instability", International Reviews Business Research Papers, Vol. 10, No. 1: 39-48.

Erim, Neşe; Türk, Armağan (2005), “Finansal Gelişme ve İktisadi Büyüme”, Kocaeli Üniversitesi Sosyal Bilimler Enstitüsü Dergisi, C. 10, S. 2: 21-45.

Everitt, Brian S.; Dunn, Graham (2001). Applied Multivariate Data Analysis, Second Edition, United Kingdom: John Wiley\&Sons Ltd.

Graff Michael; Karmann, Alexander (2006), "What Determines Finance-Growth Nexus? Empirical Evidence For Threshold Models" Journal of Economics, Vol. 87, No. 2: 127-157.

Gries, Thomas; Kraft, Manfred; Meierrieks, Daniel (2009), "Linkages Between Financial Deepening Trade Openness, and Economic Development: Causality Evidence From Subsaharan Africa”, World Development, Vol. 37, No. 12: 18491860.

Hair, Joseph F.; Black, William. C.; Babin, Barry J.; Anderson, Rolph E. (2010), “Multivariate Data Analysis A GlobalPerspective", Seventh Edition, New Jersey: Pearson.

Hamori, Shigeyuki; \&Hashiguchi, Yoshihiro (2012), "The Effect of Financial Deepening on Inequality: Some International Evidence", Journal of Asian Economics, 23(2012): 353-359.

Hasan, Iftekhar; Wachtel, Paul; Zhou, Mingming (2009), "Institutional Development, Financial Deepening and Economic Growth: Evidence From Chine", Journal of Banking \& Finance, Vol. 33, No. 1: 157-170.

Herrero, Alicia García; Santillán, Javier; Gallego, Sonsoles; Cuadro, Lucía; Egea, Carlos (2002), Latin American Finan-

cial Development in Perspective, Banco de España, https://pdfs.semanticscholar.org/f2f6/ab6bd4f50ee2a40dcc6c3651cd1a66cb0890.pdf?_ga=2.1187047771067079168.15311392861631802215.1531139286, (Erişim: 20.01.2015).

Hsu, Sara; Li, Jianjun (2012), “Ideal Financial Development and Financial Overaccumulation”, https://mpra.ub.unimuenchen.de/38035/1/MPRA_paper_38035.pdf, (Erişim: 17.03.2016).

Huang, Wei (2006), “Emerging Markets Financial Openness and Financial Development", https://ideas.repec.org/p/bri/uobdis/06-588.html, (Erişim: 10.05.2015). 
Hussain, Farah; Chakraborty, Deb Kumar (2012), “Causality Between Financial Development and Economic Growth: Evidence From an Indian State", The Romanian Economic Journal, Vol. XV, No. 45: 27-48.

International Money Fund (IMF), International Financial Statistics, http://data.imf.org/ (Erişim: 05.04.2016).

Jalil, Abdul; Feridun, Mete; Ma, Ying (2010), "Finance - Growth Nexus in China Revisited: New Evidence From Principal Components and ARDL Bounds Tests", International Review of Economics and Finance, Vol. 19, No. 2: 189-195.

Jolliffe, I. T. (2002), Principal Component Analysis, Second Edition, USA: Springer.

Jung, Woo. S. (1986), "Financial Development and Economic Growth: International Evidence”, Economic Development and Cultural Change, Vol. 34, No. 2: 333-346.

Kar, Muhsin; Nazlığlu, Şaban; Ağır, Hüseyin (2014), "Trade Openness, Financial Development and Economic Growth in Turkey: Linear and Nonlinear Causality Analysis", BDDK Bankacılık ve Finansal Piyasalar, C. 8, S. 1: 63-86.

Khan, Mohsin. S.; Senhadji, Abdelhak. S.; Smith, Bruce. D. (2001), "Inflation and Financial Depth", https://www.imf.org/external/pubs/ft/wp/2001/wp0144.pdf, (Erişim: 26.01.2015).

Kitenge, Erick (2013), “Reexamining The Relationship Between Financial Development and Economic Growth: The Case of South Africa", http://opensiuc.lib.siu.edu/gs_rp/333, (Erişim: 30.01.2016).

Landau, Sabine; Everitt, Brian S. (2004), A Handbook of Statistical Analyses Using SPSS. USA: Chapman\&Hall/CRC.

Lehman, Ann; O’Rourke, Norm; Hatcher, Larry; Stepanski, Edward J. (2005). JMP for Basic Univariate and Multivariate Statistics: A Step By Step Guide, USA: SAS Press.

Levine, Ross (1997), "Financial Development and Economic Growth: Views and Agenda", Journal of Economic Literature, Vol. XXXV, June: $688-726$.

Liang, Qi; Teng, Jian-Zhou (2006), "Financial Development and Economic Growth: Evidence From China”, China Economic Review, Vol. 17, No. 4: 395-411.

Luintel, Kul B.; Khan, Mosahid (1999), "A Quantitative Reassessment of The Finance Growth Nexus: Evidence From a Multivariate VAR", Journal of Development Economics, Vol. 60, No. 2: 381-405.

Lynch, David (1996), "Measuring Financial Sector Development: A Study of Selected Asia Pacific Countries", The Developing Economics, Vol. XXXIV-I, March: 3-32.

Mhadbi, Khalil (2014), "New Proxy of Financial Development and Economic Growth in Medium-Income Countries: A Bootstrap Panel Granger Causality Analysis", American Journal of Applied Mathematics and Statistics, Vol. 2, No. 4: 185-192.

Mahajan, Nayia; Verma, Satish (2014), "Financial Development and Economic Growth: A Case of Indian Economy", International Journal of Economics, Finance and Mangement, Vol. 3, No. 1: 15-21.

Malhotra, Naresh K. (2010), Marketing Research: An Applied Orientation, Six Edition, New Jersey: Pearson.

Nakip, Mahir (2003), Pazarlama Araştırmaları, Teknikler ve (SPSS Destekli) Uygulamalar, Birinci Baskı, Ankara: SeçkinYayıncilık.

Nzotta, Samuel Mbadike; Okereke, Emeka J. (2009), "Financial Deepening and Economic Development Of Nigeria: An Empirical İnvestigation", African Journal of Accounting, Economics Finance and Banking Research, Vol. 5, No. 5 : 52-66.

Oskay, Suna (2000), "Finansal Piyasalarda Yeni Yasal Düzenlemeler intiyacı ve Türk Finans Sistemi”, Marmara Üniversitesi Sosyal Bilimler Enstitüsü Öneri Dergisi, C. 75, S. 10: 9-18.

Öztürk, Nurettin; Barışık, Salih; Darıcı, Havva Kılıç (2010), "Gelişmekte Olan Piyasalarda Finansal Derinleşme ve Büyüme İlişkisi: Panel Veri Analizi”, ZKÜ Sosyal Bilimler Dergisi, C. 6, S. 12: 95-119.

Pituch, Keenan A.; Stevens, James P. (2015), Applied Multivariate Statistics For The Social Sciences, Analyses With SAS IBM's SPSS, Six Edition, Newyork, London: Routledge.

Sahay, Ratna;,Cihak, Martin; N’Diaye, Papa; Barajas, Adolfo; Bi, Ran; Ayala, Diana; Gao, Yuan; Kyobe, Annette; Nguyen, Lam; Saborowski, Christian; Svirydzenka, Katsiaryna; Yousefi, Seyed Reza (2015), Rethinking Financial Deepening: Stability and Growth in Emerging Markets, https://www.imf.org/external/pubs/ft/sdn/2015/sdn1508.pdf, (Erişim: 25.01.2016).

Sanguansat, Parinya (2012), Principle Component Analysis - Multidisciplinary Applications. Croatia: InTech.

Singh, Kultar (2007), Quantitative Social Research Methods, New Delhi: Sage Publications.

Uçar, Nezihe (2014), Kümeleme Analizi. Ş. Kalaycı (Ed.). SPSS Uygulamalı Çok Değişkenli İstatistik Teknikleri: 350-376. Ankara: Asil Yayın Dağıtım. 


\section{Eskişehir Osmangazi Üniversitesi IïBF Dergisi}

Varlık, Nimet (2016). “Türkiye'de Finansal Gelişme İle Finansal Kırılganlık İlişkisi, 1990-2014 Dönemi”, Ekonomik Yaklaşım, C. 27, S. 98: 141-176.

World Bank (WD), World Development Indicator, http://databank.worldbank.org/data/indicator/NY.GDP.MKTP.KD.ZG/1ff4a498/Popular-Indicators, (Erişim: 28.04.2016).

Zerbo, Eléazar (2015), "What Determines The Long-Run Growth in Sub-Saharan Africa? Exploring The Role of Energy, Trade Openness and Financia Ldevelopment in Six Countries", https://hal.archives-ouvertes.fr/hal-01238524, (Erişim: 15.01.2016). 